\title{
Orta Gelir Tuzağının Türkiye Geneli ve Düzey Alt Bölgeleri İçin Tespiti* $^{*}$
}

\author{
Ali İLHAN*, Coşkun AKDENIZ**
}

ÖZ

Bu çalışmanın amacı, orta gelir tuzağının Türkiye'nin geneli ve düzey alt bölgeleri için var olup olmadığını incelemektedir. Çalışmada ülke geneli için orta gelir tuzağının varlığı Robertson ve Ye'nin (2013) yaklaşımından hareketle geleneksel ve yapısal kırılmaya izin veren birim kök testleri vasıtasıyla analiz edilirken, düzey alt bölgeleri için başta Yakalama Endeksi (Catch-Up Index, CUI) olmak üzere istatistiki sınıflandırmalar kullanılmıștır. 1960-2018 döneminin ele alındığı ekonometrik analiz sonuçlarına göre, Türkiye ekonomisinde orta gelir tuzağı mevcut değildir. Bununla birlikte 2004-2017 dönemindeki CUI değerleri, düzey alt bölgelerinin çok büyük bir kısmının düşük gelir grubunda yer aldıklarını ve orta gelir seviyesine yükselen bazı bölgelerin de son yıllarda konumlarını kaybettiklerini göstermektedir. Bu bağlamda, Türkiye'nin orta gelir tuzağında yer almamasını yüksek gelir grubuna doğru yakınsama ile açıklamanın güçleştiğini ifade etmek mümkündür.

Anahtar Kelimeler: Türkiye Ekonomisi, Türkiye’nin Alt Bölgeleri, Orta Gelir Tuzağı, Yapısal Kırılmalı Birim Kök Testleri, Yakalama Endeksi

JEL Sinıflandırması: C22, O40, O11

\section{Determination of the Middle Income Trap for Turkey and Its Sub-Regions}

\begin{abstract}
The aim of this study is to analyse whether there is the middle income trap for general level and sub-regions of Turkey. In this study, the existence of the middle income trap was analysed for the country level through traditional and structural break unit root tests based on Robertson and Ye's (2013) approach, on the other hand the statistical classifications -mainly Catch-Up Index (CUI)- were employed for the sub-regions. According to the results of the econometric analysis discussed in the 1960-2018 period, the middle income trap is not exist for the Turkish economy. However, CUI values for the period 2004-2017 show that a large part of the sub-regions are in the low income group and some of the regions which reached to the middle income level have lost their places in recent years. In this context, it becomes difficult to explain that Turkey's hasn't been stuck in middle income trap with convergence towards to the high income group.
\end{abstract}

Keywords: Turkish Economy, Sub-Regions of Turkey, Middle Income Trap, Unit Root Tests with Structural Breaks, Catch-Up Index

JEL Classification: C22, O40, O11

Geliş Tarihi / Received: 28.08.2019 Kabul Tarihi / Accepted: 22.11.2019

\footnotetext{
* Bu çalışma, 9-10 Mart 2019 tarihlerinde düzenlenen XI. International Balkan and Near Eastern Social Sciences Congress Series'de (IBANESS) sözlü olarak sunulmuş bildirinin genişletilmiş halidir.

* Arş. Gör. Dr., Tekirdağ Namık Kemal Üniversitesi, İiBF, İktisat Bölümü, ailhan @ nku.edu.tr, ORCID: 0000-00016201-5353.

** Arş. Gör. Dr., Tekirdağ Namık Kemal Üniversitesi, İiBF, İktisat Bölümü, cakdeniz@nku.edu.tr, ORCID: 00000002-3973-754X.
} 


\section{GİRIŞ}

İktisat teorisi, düşük gelirli ülkelerin gelir düzeylerinin hızlı bir ekonomik büyüme performansı kaydederek kademeli bir şekilde yüksek gelirli ülkelere yakınsayacağını öngörmektedir. Buna göre, düşük fiziki sermaye stokuna sahip olmalarından dolayı sermaye getirileri yüksek olan bu ülkelerin gelişmiş ülkelerden sermaye, teknoloji ve teknik uzmanlık (know-how) da ithal edebilmeleri sermaye birikimlerini hızlandırmaktadır. Tüm bu gelişmeler sonucunda, düşük gelir grubundaki ülkelerin -bir üst gelir grubundaki ülkelere yakınsayacak şekilde- büyüme oranları yükselmektedir. Buna karşın iktisat teorisinin gelir farkını azaltacak öngörüleri gerçek hayatta her zaman gerçekleşmemektedir. Afrika, Güney Asya, Latin Amerika ve Orta Doğu'da yer alan çok sayıdaki ülkenin gelir düzeylerinin on yıllardır durağan ve düşük düzeylerde seyrettiği görülmektedir.

Orta gelir grubunda yer alan ülkelerin, yüksek gelir grubuna geçişi için gereken büyüme performanslarına ilişkin kaygılar gerek akademisyenler gerekse politika yapıcılar tarafından son yıllarda sıklıkla dile getirilmektedir. Buna göre, düşük gelir grubundan orta gelir grubuna geçişte uygulanan politikalar ile büyüme patikasına devam eden ülkelerin orta gelir grubuna sıkışıp kalma riski artmaktadır. Yavaşlayan büyüme oranları neticesinde uzun süre orta gelir grubunda kalan ve yakın gelecekte yüksek gelir grubuna geçiş olasıllğ̆ azalan ülkeler için söz konusu durum literatürde orta gelir tuzağı (middle income trap) olarak tanımlanmaktadır.

Orta gelir tuzağı olgusu dolaylı olarak ilk defa orta gelir grubundaki ülkelerin büyüme oranlarının 1980'lerden itibaren yavaşladığını gözlemleyen Garret (2004) tarafından dile getirilmiştir. Bununla birlikte orta gelir tuzağı kavramı literatürde ilk kez Dünya Bankasının 2007 yılında yayımladığı "Bir Doğu Asya Rönesansı: Ekonomik Büyüme İçin Fikirler (An East Asian Renaissance: Ideas for Economic Growth)” adlı raporda kullanılmıştır. Dünya Bankası uzmanlarından Gill ve Kharas (2007) tarafindan hazırlanan raporda orta gelirli ülkelerin, imalat sanayi gibi olgun endüstrilerde düşük ücret avantajına sahip yoksul ülkelere karş1 rekabet gücünün zayıflamasından veya teknoloji endüstrilerinde hâkimiyeti ellerinde bulunduran yenilikçi zengin ülkelere yakınsamada yaşadığı güçlüklerden dolayı bu ülkelere nazaran daha yavaş bir şekilde büyüdüğü ortaya konulmuştur.

Orta gelir tuzağı, yapısal dönüşümünü henüz tamamlayamamış ekonomilere benzer şekilde Türkiye ekonomisi için de sürdürülebilir ekonomik büyüme açısından ciddi bir risk unsuru oluşturmaktadır. Kasım 2000 ve Şubat 2001 krizlerinin ardından Güçlü Ekonomiye Geçiş Programı (GEGP) ile birlikte birçok alanda yapısal reform gerçekleştiren Türkiye ekonomisi, "Büyük Sakinlik" (Great Moderation) dönemindeki küresel likidite bolluğunun da etkisiyle kayda değer bir büyüme performansı yakalamış ve orta gelir grubuna yükselmiştir. Buna karşın mevcut kişi başına gelirin uzun süredir yüksek gelir grubu seviyesinin bir hayli altında seyretmesi, bu gelir grubunun bir tuzak mı yoksa sadece bir basamak mı olacağına ilişkin tartışmaları da beraberinde getirmiştir. Bu bağlamda, yakın gelecekte yüksek gelirli ülkeler grubuna geçmesi pek olası gözükmeyen Türkiye için orta gelir tuzağı riskinin incelenmesi gerekliliği ortaya çıkmıştır.

Literatürde orta gelir tuzağına ilişkin Türkiye'yi konu alan çalışmalar incelendiğinde, ağırlıklı olarak ülke geneli için tuzağın varlığının tespitine odaklanıldığı görülmektedir. Bölgesel gelir düzeyleri arasındaki farkların dikkate alınarak tuzağın varlı̆̆ının alt bölgeler açısından da incelendiği çalışmalar ise son derece kısıtlıdır. Bununla birlikte ülke genelinde orta gelir tuzağının varlığını farklı dönemler için analiz eden ve orta gelir tuzağının olmadığını tespit eden çalışmaların bazılarında tuzağa yakalanılmamasının yüksek gelir grubuna doğru yakınsama ile açıklandığ görülmektedir.

Bu bağlamda çalışmanın amacı, orta gelir tuzağının Türkiye geneli ve düzey alt bölgeleri için var olup olmadığını incelemektir. Türkiye geneli için tuzağın varlığının 1960-2018 dönemi 
için tespit edilmesinin hedeflendiği çalışmada Robertson ve Ye'nin (2013) yaklaşımından hareketle geleneksel ve yapısal kırılmaya izin veren birim kök testleri kullanılmıştır. Robertson ve Ye'nin (2013) yaklaşımı ile sadece orta gelir tuzağının olup olmadığı tespit edilmektedir. Orta gelir tuzağı olasılığına ve yakınsama/ıraksamaya dair kesin yargılara varılamamaktadır. Dolayısıyla yakınsama veya ıraksamadan bahsedebilmek için ilave analizlere ihtiyaç duyulmaktadır. Bu doğrultuda hem ülke geneli hem de düzey alt bölgeleri için -başta Yakalama Endeksi (Catch-Up Index, CUI) yaklaşımı olmak üzere- istatistiki sınıflandırmalar kullanılarak 2004-2017 arasını kapsayan dönemde orta gelir tuzağı riskine ilişkin değerlendirmeler yapılmıştır.

Çalışmanın girişi izleyen kısmında orta gelir tuzağının teorik ve kavramsal çerçevesi ortaya koyulmuştur. Üçüncü bölümde orta gelir tuzağının tespitinde kullanılan istatistiki sınıflandırmaya dayalı yaklaşımlar ve ekonometrik yöntemler açıklanmıştır. Dördüncü bölümde Türkiye'de orta gelir tuzağının tespitine yönelik çalışmalar incelenmiştir. Beşinci bölümde, ekonometrik analize ilişkin kullanılan veri seti ve metodolojiye yer verilirken sonraki bölümde ulaşılan bulgular açıklanmıştır. Çalışma, bulgulara yönelik değerlendirmelerin yer aldığı sonuç bölümü ile tamamlanmıştır.

\section{ORTA GELIR TUZAĞI: TEORİK VE KAVRAMSAL ÇERÇEVE}

"Tuzak" kavramı geleneksel olarak, karşılaştırmalı statik denge durumunun ötesinde ve kısa vadeli dış faktörlerin değiştiremediği kararlı bir ekonomik denge durumunu ifade etmek amacıyla kullanılmaktadır. Bu doğrultuda orta gelir tuzağını, kişi başına gelirdeki artışa yardımcı ancak sürdürülebilirliği mümkün olmayan bir faktörün etkisinin, kişi başına gelir düzeyini başlangıç seviyesine döndürebilecek kısıtlayıcı diğer faktörlerle dengelenmesi durumu olarak tanımlamak mümkündür (Cai, 2012: 51).

Literatürde orta gelir tuzağını farklı yaklaşımlar üzerinden açıklamaya yönelik çok sayıda çalışma bulunmaktadır. Söz konusu çalışmalar orta gelir tuzağını; arz, talep, gelir eşitsizliği, ekonomik gelişme evreleri, politik iktisat ve büyümede yavaşlama gibi çeşitli olgular üzerinden açıklamışlardır (Ünlü ve Yıldız, 2017: 88).

Barro ve Sala-i-Martin'in (1995) yakınsama hipotezine göre ekonomik büyüme; yatırım oranları, beşeri sermaye birikimi, devlet politikaları ve altyapı koşulları gibi çok sayıda faktöre bağlıdır. Ekonomik büyümenin ilk aşamalarında söz konusu faktörlerdeki iyileşmeler büyümedeki yakınsamayı hızlandırmaktadır. Buna karşın sonraki aşamalarda azalan marjinal getiri kanununun etkileri hissedilmektedir. Sermayenin marjinal verimliliğinin azalması ile birlikte faktör birikimine dayalı stratejilerin büyüme üzerindeki pozitif etkileri ortadan kaybolmaktadır. Diğer bir ifadeyle toplam faktör verimliliğinin esas alındığı içsel bir büyüme modeli yerine fiziki sermaye birikimine dayalı bir üretim modeli, nihayetinde sıfır büyüme ile dengelenmektedir. Emek verimliliğini arttıracak hamleleri gerçekleştiremeyen ekonomiler denge durumunu bozamamakta ve orta gelir tuzağına yakalanmaktadır.

Orta gelir tuzağı mekanizmasını toplam faktör verimliliği üzerinden açıklayan Eichengreen vd.'ne (2011) göre orta gelirli ülkeler için büyümedeki durgunluğun temel sebebi, toplam faktör verimliliğindeki yavaşlamadır. Buna göre, hızlı büyüyen bir ekonomideki yavaşlamada sermaye birikimindeki azalmanın payı \%15 iken: toplam faktör verimliliğindeki azalmanın payı ise \%85'tir. Benzer şekilde; Daude ve Fernandez-Arias da (2010), Latin Amerika ülkelerindeki orta gelirli ülkelerin gelişmiş ülkelerle gelir farkını kapayamamalarının faktör birikiminden ziyade verimlilik artışındaki yavaşlamadan kaynaklandığı sonucuna ulaşmışlardır.

Orta gelir tuzağına yakalanmada verimlilik yavaşlamalarının önemine vurgu yapan Agenor ve Canuto (2012), beşeri sermayenin nitelikleri ile ekonomideki sektörleri, temel ve 
gelişmiş olarak ikiye ayıran matematiksel bir model geliştirmişlerdir. Buna göre, yüksek gelirli ülke yüksek beceriye sahip nitelikli işgücü ile tasarım gibi yenilikçi ve gelişmiş üretim faaliyetlerine yatırım yaparken orta gelirli ülke nispeten daha düşük eğitim seviyesine sahip işgücü ile basit üretim faaliyetlerine yönelmektedir. Orta gelirli ülkelerde, eğitimli işgücü sayısının azlığı ve bunların da çok azının ekonominin yapısına uygun olması, eğitim yatırımlarındaki teşvikleri de azaltmaktadır. Bununla birlikte eğitimli işgücünün sayıca az olması, firmaların daha verimli olan tasarım ve yenilik faaliyetlerine girişmeleri önünde de engel oluşturmaktadır. Tüm bu faktörler neticesinde ülke orta gelir tuzağına sürüklenmektedir.

Mert'e (2014) göre; toplam faktör verimliliğini arttıracak ve orta gelirli ülkelerin tuzağa yakalanmamalarını sağlayacak Ar-Ge faaliyetleri, ekonomideki talep koşullarına göre şekillenmektedir. Bir ekonomide, üreticilerin üretim yöntemine veya ürüne ilişkin yeni arayışlar içerisine girmeleri talebin değişeceğine dair beklentilere bağlıdır. Piyasada henüz bulunmayan ancak ihtiyaçlar gözetilerek üretilmesi muhtemel yeni mallar için talep koşullarının ortaya çıkması ya da çıkarılması gerekmektedir. Dolayısıyla orta gelir tuzağı olgusunda ekonominin talep boyutu göz ardı edilmemelidir. Geliştirmiş olduğu yöntemle büyüme oranlarında iç talebin ve dış talebin katkılarını analiz eden Mert (2014), orta gelir tuzağından kurtulmuş veya yüksek gelir grubuna yakınsayan ülkelerde iç talebin büyümeye katkısının dış talepten daha yüksek olduğu sonucuna ulaşmıştır.

Orta gelir tuzağı mekanizmasını işler hale getiren bir başka unsur gelir dağılımındaki eşitsizliktir. Literatürde, orta gelir tuzağının eşitsizlik boyutunun -ekonomik büyüme ve gelir eşitsizliği arasındaki ilişkiyi ortaya koyan- Kuznets Eğrisi ${ }^{1}$ üzerinden açıklandığı görülmektedir. Buna göre gelir eşitsizliği, ekonomik büyümenin ilk aşamalarındaki hızlı büyümenin bedelidir. Düşük gelirli bir ülkede, büyüme sürecinde tarım sektörünün yerini sanayi sektörü aldıkça en alt ve en üst gelir grupları arasındaki fark açılırken belirli bir orta gelir düzeyine ulaşıldıktan sonra eğitim düzeyinin ve sanayileşmenin artması ile birlikte gelir eşitsizliği azalmaktadır (Ozturk, 2016: 729).

Egawa (2013), orta gelir grubundaki üç Asya ülkesinin (Çin, Tayland ve Malezya) verileri ile orta gelir tuzağında gelir eşitsizliğinin rolünü Kuznets hipotezi ve temel ihtiyaçlar yaklaşımı çerçevesinde incelemiştir. Gelir dağılımındaki eşitsizliğin ekonomik büyüme önünde sorun teşkil ettiği sonucuna ulaşan Egawa'ya göre gelir piramidinin en altındaki kesimin eğitim ve sağlik hizmetlerine yetersiz erişimi, bu kesimin yüksek teknolojili üretim süreçlerine katılımını engellemektedir. Bölgesel gelir farklılarını azaltacak, gelirin yeniden dağılımını sağlayacak ve beşeri sermayenin niteliğini güçlendirecek devlet politikalarının olmadığ durumlarda orta gelirli ülkeler için ekonomik büyümenin yavaşlaması kaçınılmazdır.

Orta gelir tuzağını açıklamaya yönelik temel yaklaşımlardan biri de ekonomik gelişme evreleri yaklaşımıdır. Ekonomik gelişme evreleri yaklaşımı, temelde ekonomide gerçekleşen yapısal değişim süreçlerine odaklanmaktadır. $\mathrm{Bu}$ doğrultuda ekonomik gelişme evreleri yaklaşımında orta gelir tuzağı; endüstriyel gelişim süreçleri, nüfus, emeğin sektörler arası geçişi, teknolojik yetenekler gibi olgular ekseninde açıklanmaktadır (Ünlü ve Yıldız, 2017: 96-104).

Doğu Asya ülkelerinin endüstriyel gelişim süreçleri üzerinden orta gelir tuzağı kavramını ele alan Ohno'ya (2009) göre, düşük gelirli bir ülkenin sanayileşme sürecini tamamlayabilmesi için geçirmesi gereken beş gelişme aşaması vardır. Ekonomik açıdan kırılgan bir yapıya sahip, ekonomik faaliyetleri madencilik ve tek çeşit tarım ürünleri ile sınırlı ve dış yardımlara bağımlı olan düşük gelirli ülkeler başlangıç aşamasında bulunmaktadır. Birinci

\footnotetext{
${ }^{1}$ Kuznets Eğrisi, S. Kuznets'in 1955 yılında yayınladığı “Economic Growth and Income Inequality” adlı çalışmasında gelir eşitsizliği ve ekonomik büyüme arasındaki ilişkiyi gösteren ters U şeklinde bir eğridir (Ozturk, 2016: 729).
} 
aşamaya geçiş ise doğrudan yabancı yatırımların ülkeye girmesiyle başlamaktadır. Düşük teknolojili ürünlerin üretildiği bu süreçte, düşük gelirli kişiler için istihdam ve gelir olanağ 1 yaratılırken içsel değer düşük düzeyde kalmaktadır. İkinci aşamada, doğrudan yabancı yatırımların birikimi ve üretimin genişlemesiyle birlikte üretim süreçlerinde kullanılan girdilerin yurt içi arzı artmaktadır. Fiziki girdilerin yurt içinde üretilmesiyle sanayinin hacimsel olarak büyümesine karşın üretim sürecinin yabancıların yönetiminde olmasından dolayı yaratılan içsel değer arzu edilen seviyeye ulaşamamaktadır. Gelişme evrelerinde geçişin en zor olduğu ve geçiş sürecinde ülkelerin genellikle orta gelir tuzağına yakalandığ evre üçüncü aşamadır. Beşeri sermaye birikimiyle bilginin ve yeteneklerin içselleştirildiği bu aşamada, yerleşikler üretim sürecinin tüm aşamalarında yabancıların yerini almakta ve ülke yüksek kaliteli sanayi ürünlerinin dinamik bir ihracatçısı konumuna gelmektedir. Dördüncü ve son aşamada ise, ülke yeni ürünler üretecek ve küresel piyasa trendlerine öncülük edecek yetkinliğe ulaşmaktadır.

\section{ORTA GELİR TUZAĞININ TESPITTINDE KULLANILAN YÖNTEMLER}

Literatürde, orta gelir tuzağı kavramına ilişkin genel kabul görmüş bir tanımın bulunmaması söz konusu olgunun araştırmacılar tarafından farklı şekillerde tanımlanmasına neden olmuştur. $\mathrm{Bu}$ durum, bazı çalışmalarda bir ülkenin orta gelir tuzağına sıkışmış, bazı çalışmalarda ise tuzaktan kurtulmuş ülke olarak tanımlanmasına yol açmıştır. Örneğin, Woo'ya (2012) göre Polonya orta gelir tuzağında değilken Felipe vd. (2012) ile Robertson ve Ye (2013), Polonya’yı orta gelir tuzağında tanımlamaktadır (Pruchnik ve Zowczak, 2017: 3).

Tablo 1: Orta Gelir Tuzağının Tespitinde Kullanılan Yöntemler

\begin{tabular}{ll}
\hline \multicolumn{1}{c}{ Yöntemler } & \multicolumn{1}{c}{ Çalışmalar } \\
\hline Sabit gelir eşikleri & Eichengreen vd. 2013, Aiyar vd., 2013, Spence, 2011 \\
Nispi gelir eşikleri & Agenor ve Canuto, 2012, Im ve Rosenblatt, 2013, Bulman vd. 2014 \\
Zaman eşikleri & Felipe vd. 2012 \\
Endeksler & Woo, 2012, Hawksworth, 2014 \\
Ekonometrik yöntemler & Robertson ve Ye, 2013 \\
\hline \hline
\end{tabular}

Orta gelir tuzağının tespitine yönelik literatürde en çok kullanılan yöntemleri Tablo 1'de gösterildiği üzere beş grupta sınıflandırmak mümkündür.

\subsection{Sabit Gelir Eşikleri}

Sabit gelir eşikleri yöntemi, mutlak bir orta gelir eşiğine dayanmaktadır. Bu yöntemin kullanıldığı çalışmalarda, eşikler için Dünya Bankası'nın her yıl güncellediği sınıflandırmaya istinaden mutlak bir değer belirlenmektedir. Tablo 2'de Dünya Bankası'nın 2018 yılında ülkelerin kişi başına düşen gayri safi milli hasıla (GSMH) değerlerini baz alarak oluşturduğu sinıflandırma yer almaktadır (Glawe ve Wagner, 2016: 513). 
Tablo 2: Dünya Bankasının Gelir Grupları Sınıflandırması

\begin{tabular}{|c|c|}
\hline Sinıflandırma & Gelir Aralığı \\
\hline Düşük gelirli ekonomiler & $\leq 1025 \$$ \\
\hline Alt-orta gelirli ekonomiler & $1026 \$-3.995 \$$ \\
\hline Üst-orta gelirli ekonomiler & $3.996 \$-12.375 \$$ \\
\hline Yüksek gelirli ekonomiler & $\geq 12.376 \$$ \\
\hline
\end{tabular}

Kaynak: Dünya Bankası, (https://datahelpdesk.worldbank.org/knowledgebase/articles/906519-world-bankcountryand-lending-groups, Erişim Tarihi: 30.09.2019)

Tablo 2'deki sınıflandırmaya göre, gelir düzeyi 1025 \$ ve altında olan ülkeler düşük gelirli, 1026 \$ ile 3.995 \$ arasında olan ülkeler alt-orta gelirli, 3.996 \$ ile 12.375 \$ arasinda olan ülkeler üst-orta gelirli, 12.376 \$ ve üstünde olan ülkeler ise yüksek gelirli ülkeler olarak tanımlanmaktadır.

Orta gelir tuzağının tespitinde sabit gelir eşiklerini kullanan Eichengreen vd. (2013) orta gelir tuzağını, yükselen piyasa ekonomilerinin büyümelerindeki yavaşlama olarak tanımlamaktadır. Bu yaklaşıma göre, $t$ döneminde büyümesi yavaşlayan bir ekonomiyi orta gelir tuzağında tanımlayabilmek için şu üç koşulun sağlanması gerekmektedir:

i. $g_{t, t-n} \geq 0.035$ ( $t$ döneminden önceki yedi yıllık süreçte kişi başına gelirdeki ortalama büyüme oranının $\% 3.5$ veya daha fazla olması),

ii. $g_{t, t+n}-g_{t, t-n} \geq 0.02$ ( $t$ döneminden sonraki yedi y1llık süreçte büyüme oranında en az $\% 2$ düşüş olmasi),

iii. $y_{t} \geq 10.000$ (Kişi başına düşen gelirin 2005 fiyatlarıyla satın alma gücü paritesine göre 10.000 \$'dan yüksek olmas1 gerekmektedir).

Eichengreen vd. (2013) büyümede yavaşlama olasılığının en yüksek olduğu iki gelir düzeyi belirlemişlerdir. Buna göre, kişi başına gelir düzeyinin 10.000-11.000 \$ ile 15.000$16.000 \$$ arasında olduğu ülkelerde büyümede yavaşlama ve orta gelir tuzağına yakalanma riski artmaktadir.

Benzer bir şekilde Aiyar vd. (2013) orta gelir tuzağını büyümede yavaşlamanın özel bir durumu olarak nitelendirmektedir. Büyümede yavaşlamalar, temel bir koşullu yakınsama çerçevesi tarafından tahmin edilen büyüme patikasından ani, büyük ve kalıcı sapmalar olarak tanımlanmaktadır.

Aiyar vd. (2013) büyümede yavaşlamanın tespiti için kalıntıları (residuals) kullanmıştır. Kalıntılar $\left(\operatorname{res}_{i}^{t}\right) i$ ülkesinin $t$ zamanında fiili ve tahmini büyüme değerleri arasındaki farkı ifade etmektedir. $(t-1)$ ve $(t+1)$ dönemleri beşer yıllık dönemler olarak tanımlanmaktadır. Buna göre, $i$ ülkesinin $t$ zamanındaki kalıntısı, $(t-1)$ döneminden daha küçükse ve $(t+1)$ döneminde de daha küçük olmaya devam ediyorsa söz konusu ülke için büyümede yavaşlama söz konusudur. Diğer bir ifadeyle, büyümede yavaşlamanın tanımlanması için büyüme düşüşlerinin en az on yıl sürmesi gerekmektedir. 138 ülke için 1955-2009 dönemini kapsayan çalışmada 123 büyüme yavaşlaması tespit edilirken, düşük ve yüksek gelirli ülkelere nazaran orta gelirli ülkelerde daha çok büyüme yavaşlaması gerçekleştiği sonucuna ulaşılmıştır. Orta gelir sınıflandırmasına ilişkin alt eşiğin 1.000 \$-3.000 \$ üst eşiğin ise 12.000 \$-16.000 \$ arasında 
olduğu 15 farklı gelir eşiğinin tespit edildiği çalışmada alt eşik olarak 2.000 \$, üst eşik olarak 15.000 \$ alınmıştır.

\subsection{Nispi Gelir Eşikleri}

Orta gelir tuzağının tespitinde nispi gelir eşiklerini kullanan çalışmalarda, nispi gelir düzeyleri için yakalama ölçütleri (benchmark) kullanılmaktadır. ABD’nin yirminci yüzyılın başlarından itibaren dünyanın ekonomik lideri olarak kabul edilmesinden dolayı bu çalışmalarda genellikle ABD'nin referans ülke olarak alındığı görülmektedir.

Im ve Rosenblatt (2013), çalışmalarında bir ülkenin bir üst gelir grubuna girme olasılığına odaklanmışlardır. Bu doğrultuda öncelikle ABD'yi ölçüt ülke alarak, ülkelerin gayri safi yurt içi hasılalarını (GSYIH) ABD'nin GSYIH'sine oranlayarak nispi gelir düzeylerini tespit etmişlerdir. Ardından iki alternatif nispi gelir grubu setiyle iki geçiş matrisi oluşturmuşlar ve diğer çalışmalardan farklı olarak orta gelir aralığını düşük-orta, orta-orta ve yüksek-orta olmak üzere üç alt gruba bölmüşlerdir. Tablo 3'den de görüleceği üzere, birinci matriste 0.15-0.30 düşük-orta, $0.30-0.45$ orta-orta, $0.45-0.60$ ise yüksek-orta gelir grubu olarak tanımlanmıştır. İkinci matriste ise 1/16-1/8 düşük orta, 1/8-1/4 orta-orta, 1/4-1/2 yüksek-orta gelir grubunu ifade etmektedir. Im ve Rosenblatt'ın (2013) Maddison Project veri tabanını kullanarak 1950-2008 dönemi için 127 ülkeyi analiz ettikleri çalışmalarının bulguları Tablo 3'te gösterilmektedir.

Tablo 3: Üst Gelir Grubuna Geçiş Matrisleri

\begin{tabular}{cccc}
\hline \multicolumn{1}{c}{ Geçiş Matrisi I } & \multicolumn{2}{c}{ Geçiş Matrisi II } \\
\hline $\begin{array}{c}\text { X ülkesinde kişi başına } \\
\text { GSYİH / ABD'de kişi başına } \\
\text { GSYİH }\end{array}$ & $\begin{array}{c}\text { Bir üst gruba } \\
\text { geçiş olasılığı }\end{array}$ & $\begin{array}{c}\text { X ülkesinde kişi başına GSYIH } \\
\text { / ABD'de kişi başına GSYİH }\end{array}$ & $\begin{array}{c}\text { Bir üst gruba geçiş } \\
\text { olasılığı }\end{array}$ \\
\hline$<0.15$ & $\% 5$ & $<1 / 16$ & $\% 7$ \\
$0.15-0.30$ & $\% 17$ & $1 / 16-1 / 8$ & $\% 16$ \\
$0.30-0.45$ & $\% 29$ & $1 / 8-1 / 4$ & $\% 18$ \\
$0.45-0.60$ & $\% 34$ & $1 / 4-1 / 2$ & $\% 15$ \\
\hline \hline
\end{tabular}

Kaynak: (Im ve Rosenblatt, 2013)

Birinci geçiş matrisine göre, orta gelirli bir ülke olma ve bu durumu sürdürme olasıllı̆g düşük veya yüksek gelirli bir ülke olma ve bu durumu sürdürme olasılığından daha düşüktür. Orta-orta gelir grubundaki ülkelerin, negatif şoklara maruz kalabilmeleri bir alt gelir grubuna düşmeleri ile sonuçlanabilmektedir. Buna karşın alt gelir grubuna geçişler üst gelir grubuna geçişlerden daha düşük sıklıkta meydana gelmiştir. Bununla birlikte ikinci geçiş matrisine göre alt-orta gelir grubundaki ülkelerin bir alt gelir grubuna düşme olasıllğı bir üst gelir grubuna düşme olasılığından daha fazladır.

\subsection{Zaman Eşikleri}

Zaman eşikleri yöntemi, orta gelir tuzağını ülkelerin bulundukları gelir grubundan bir üst gelir grubuna yükselmelerinde geçen süre ile açılamaktadır. Buna göre, ülkelerin orta gelir grubunda yer alıp almadıkları mutlak bir eşik değer esas alınarak yapılan sınıflandırmada ile belirlenmektedir. Ardından orta gelir grubunda olduğu tespit edilen ülkenin, tuzağa yakalanıp yakalanmadığı ise bu gelir grubunda kaç yıl kaldığına bağlıdır. 
Felipe vd. (2012), Dünya Bankası'nın sınıflandırmasına benzer şekilde ülkeleri dört gruba ayırmıştır. 124 ülke için 1950-2010 dönemini kapsayan çalışmada 2.000 \$'ın altındaki ülkeler düşük, 2.000-7.250 \$ aralığındaki ülkeler alt-orta, 7.250-11.750 \$ aralığındaki ülkeler üst-orta, 11.750 üstündeki ülkeler ise yüksek gelirli olarak sınıflandırılmıştır. Analizde yer alan ülkelerin büyüme performanslarına göre yapılan değerlendirmelere göre, alt-orta gelir grubunda 28 yıl veya daha fazla üst-orta gelir grubunda ise 14 yıl veya daha fazla kalan ülkelerin tuzağa yakalandığı sonucuna ulaşılmıştır. Bununla birlikte alt-orta gelir grubunda bulunan bir ülkenin tuzağa yakalanmadan üst-orta gelir grubuna geçişi için büyüme hızının ortalama \%4.7, üst-orta gelir grubunun yüksek gelir grubuna geçişi için ise \%3.5 olması gerektiği hesaplanmıştır.

\subsection{Endeksler}

Literatürde, orta gelir tuzağının tespitinde endekslerden de faydalanıldığı görülmektedir. $\mathrm{Bu}$ endekslerden en bilineni Woo' nun (2012) geliştirmiş olduğu yakalama endeksidir (Catch-Up Index, CUI).

CUI, ilgili ülkenin kişi başına düşen gelirinin ABD'nin kişi başına düşen gelirine oranlanması ile hesaplanmaktadır. Hesaplamalarda ABD'nin referans ülke alınması ise ABD'nin 1920 'den bu yana dünyanın ekonomik lideri olduğuna dair uzlaşı ile açıklanmaktadır. Buna göre,

$>$ CUI $<\% 20$ ise ülke düşük gelirli,

$>\% 20<$ CUI $<\% 55$ ise ülke orta gelirli,

$>$ CUI $>\% 55$ ise ülke yüksek gelirlidir.

Çalışmaya göre, 1960-2008 döneminde CUI değeri \%20-\%55 aralığındaki ülkelerin orta gelir grubunda olmakla birlikte tuzağa yakalandıkları kabul edilmektedir.

\subsection{Ekonometrik Yöntemler}

Orta gelirli ülkelerin tuzakta olup olmadığ genellikle istatistiki yöntemlerle belirlenmeye çalışılmaktadır. Robertson ve Ye (2013) ise farklı bir yaklaşım ile orta gelir tuzağının tespitinde ekonometrik yöntem kullanmıştır. Tuzağın tespitinde ekonometrik yöntem kullanımı, büyümede yavaşlamalar, stokastik trendler ve yapısal kırılmalar gibi kısa vadeli gelişmelerin orta gelir tuzaklarından izole edilebilmesine de olanak sağlamaktadır (Koçak ve Bulut, 2014: 12).

Robertson ve Ye'nin (2013) tuzağın tespitine yönelik yaklaşımı aslında iki aşamalı bir yaklaşımdır. İlk aşamada, hangi ülkelerin orta gelir grubunda yer aldığ belirlenmiştir. Bunun tespitinde nispi gelir eşikleri yöntemi kullanılmış ve ABD'nin GSYİH'sinin \%8'i ile \%36's1 arasında olan ülkeler orta gelirli ülkeler olarak tanımlanmıştır. Ardından ilgili ülkelerin ve ABD'nin GSYİH verileri kullanılarak oluşturulan yeni seri durağanlık testlerine tabi tutulmuş ve serinin durağan olması halinde ülkelerin tuzağa yakalandıkları sonucuna ulaşı1mıştır.

Robertson ve Ye'nin (2013) yaklaşımında durağanlık analizine tabi tutulacak serinin elde edilmesi amacıyla A ülkesinin GSYİH'sinin doğal logaritmasından ABD'nin GSYİH'sinin doğal logaritması çıkarılmaktadır.

$$
X_{t}=\ln G S Y I H_{A, t}-\ln G S Y I H_{A B D, t}
$$

Durağanlık analizi sonucunda $X_{t}$ serisi için $H_{0}$ hipotezi reddedilirse, diğer bir ifadeyle seri durağan çıkarsa A ülkesinin orta gelir tuzağında olduğu kabul edilmektedir. 


\section{LITERATÜR TARAMASI}

Literatürde, Türkiye için orta gelir tuzağının varlığını tespit etmeye yönelik çalışmaları iki grupta toplamak mümkündür. İlk grupta, istatistiki sınıflandırmalara dayanılarak oluşturulan sabit ve nispi gelir eşiklerinin kullanıldığı çalışmalar bulunmaktadır. Çalışmaların birçoğunda Türkiye'nin orta gelir tuzağında veya tuzağa yakalanma riskinin yüksek olduğu sonucuna ulaşılmıştır (Tablo 4).

Tablo 4: Orta Gelir Tuzağının Varlığını İstatistiki Yöntemlerle Analiz Eden Çalışmalar

\begin{tabular}{|c|c|c|c|}
\hline Çalışma & Yöntem & Zaman Aralığı & Bulgular \\
\hline Öz (2012) & Nispi Gelir Eşikleri & $1960-2010$ & Türkiye orta gelir tuzağındadır. \\
\hline Y1lmaz (2014) & Nispi Gelir Eşikleri & $1960-2010$ & Türkiye orta gelir tuzağındadır. \\
\hline Bal (2016) & Sabit ve Nispi Gelir Eşikleri & $1950-2014$ & Türkiye orta gelir tuzağındadır. \\
\hline Ay vd. (2016) & Sabit ve Nispi Gelir Eşikleri & $1950-2014$ & $\begin{array}{l}\text { Türkiye yüksek orta gelir tuzağı riski } \\
\text { taşımaktadır. }\end{array}$ \\
\hline $\begin{array}{l}\text { Akbulut ve Yildız } \\
\text { (2017) }\end{array}$ & Sabit ve Nispi Gelir Eşikleri & $1950-2014$ & Türkiye orta gelir tuzağındadır. \\
\hline $\begin{array}{l}\text { Sarıbaş ve Ursavaş } \\
\text { (2017) }\end{array}$ & Sabit ve Nispi Gelir Eşikleri & $1950-2014$ & Türkiye orta gelir tuzağını aşmıştır. \\
\hline Konya vd. (2017) & Sabit ve Nispi Gelir Eşikleri & 1990-2016 & $\begin{array}{l}\text { Türkiye orta gelir tuzağında değildir. } \\
\text { Bununla birlikte orta gelir tuzağına } \\
\text { yakalanma riski taşımaktadır. }\end{array}$ \\
\hline $\begin{array}{l}\text { Alkan ve Ümit } \\
\quad \text { (2018) }\end{array}$ & Nispi Gelir Eşikleri & $1980-2015$ & Türkiye orta gelir tuzağındadır. \\
\hline
\end{tabular}

İkinci grupta ise Robertson ve Ye'nin (2013) yaklaşımından hareketle ekonometrik yöntemlerin kullanıldığı çalışmalar yer almaktadır.

Tablo 5: Orta Gelir Tuzağının Varlığını Ekonometrik Yöntemlerle Analiz Eden Çalışmalar

\begin{tabular}{|c|c|c|c|}
\hline Çalışma & Yöntem & Zaman Aralığı & Bulgular \\
\hline $\begin{array}{l}\text { Koçak ve Bulut } \\
\text { (2014) }\end{array}$ & $\begin{array}{l}\text { Lee-Strazicich, Carrion-i } \\
\text { Silvestre vd. }\end{array}$ & $1950-2010$ & $\begin{array}{l}\text { Türkiye orta gelir tuzağında değildir. ABD } \\
\text { ile gelir farkını kapatma eğilimindedir. }\end{array}$ \\
\hline $\begin{array}{l}\text { Kesgingöz ve Dilek } \\
\text { (2016) }\end{array}$ & $\begin{array}{l}\text { ADF, PP, Zivot-Andrews, } \\
\text { Lumsdaine-Papell }\end{array}$ & $1960-2014$ & Türkiye orta gelir tuzağında değildir. \\
\hline $\begin{array}{l}\text { Ünlü ve Y1ld1z } \\
\text { (2018) }\end{array}$ & ADF, Narayan ve Popp & $1950-2014$ & Türkiye orta gelir tuzağında değildir. \\
\hline $\begin{array}{l}\text { Tiraşoğlu ve } \\
\text { Karasaç (2018) }\end{array}$ & $\begin{array}{l}\text { ADF, PP, Lee-Strazicich, } \\
\text { Lumsdaine-Papell }\end{array}$ & 1960-2016 & $\begin{array}{l}\text { Türkiye orta gelir tuzağında değildir. ABD } \\
\text { ile gelir farkını kapatma eğilimindedir. }\end{array}$ \\
\hline $\begin{array}{l}\text { Tiftikçigil vd. } \\
\text { (2018) }\end{array}$ & $\begin{array}{l}\text { ADF, Ng-Perron, KSS, } \\
\text { Kruse, Sollis, CHLL }\end{array}$ & $1969-2015$ & Türkiye orta gelir tuzağında değildir. \\
\hline Manga vd (2019) & Carrion-i Silvestre vd. & $1950-2014$ & $\begin{array}{l}\text { Türkiye orta gelir tuzağında değildir. ABD } \\
\text { ile gelir farkını kapatma eğilimindedir. }\end{array}$ \\
\hline
\end{tabular}


Çalışmaların tamamında Türkiye'nin orta gelir tuzağında yer almadığı tespit edilmiştir. Bununla birlikte bazı çalışmalarda, orta gelir tuzağında olunmaması yüksek gelir grubundaki ülkelere doğru bir yakınsamanın sonucu olarak değerlendirilmiştir (Tablo 5).

\section{YÖNTEM}

Çalı̧̧mada öncelikle Türkiye'de düzey alt bölgeler için orta gelir tuzağı riskinin tespit edilebilmesi için -başta CUI olmak üzere- istatistiki sınıflandırmaya dayalı yöntemler kullanılmıştır. Türkiye'de düzey alt bölgelerine/illerine ilişkin kişi başına GSYİH verilerinin kısıtlı bir dönem için var olması, orta gelir tuzağı riskinin analizinde ekonometrik yöntemler yerine istatistiki sınıflandırmaya dayalı yöntemlerin kullanılmasına neden olmuştur.

Literatürde, CUI yönteminin ülke geneli için orta gelir tuzağının tespitinde kullanıldığı görülmektedir. Bununla birlikte yöntem, bölgelerin/illerin orta gelir tuzağı riskini değerlendirmek için de uygun bir yöntemdir. Yeldan vd. (2012), Türkiye'de düzey alt bölgelerinin orta gelir tuzağını Felipe vd. (2012) ve Eichengreen'in vd.'nin (2011) istatistiki sinıflandırmaya dayalı yöntemleri ile analiz etmiştir. CUI yönteminin de temelde istatistiki sinıflandırmaya dayalı olması, çalışmamızda bu yöntemin de tercih edilmesine neden olmuştur.

CUI değerlerinin hesaplanmasında, düzey alt bölgelerin/illerin kişi başına GSYİH serileri ABD'nin kişi başına GSYIH serilerine oranlanmıştır. Referans ülke olarak, -Yeldan vd.'nin (2012) düzey alt bölgelere ilişkin yapmış oldukları analizlere benzer şekilde- ABD tercih edilmiştir.

Analizlerde kullanılan veriler yıllık olup 2004-2017 dönemini kapsamaktadır. Düzey alt bölgeler için kullanılan kişi başına GSYİH serileri Türkiye İstatistik Kurumu'nun (TÜİK) veri tabanından, ABD için kullanılan kişi başına GSYIHH serileri Dünya Bankası'nın veri tabanından alınmıştır. Daha önce açıklandığı için söz konusu yöntemlerin metodolojisine bu kısımda yer verilmemiştir.

Orta gelir tuzağının Türkiye geneli için sınanmasında ise Robertson ve Ye'nin (2013) yaklaşımından hareketle geleneksel ve yapısal kırılmalı birim kök testleri kullanılmıştır. Ekonometrik analizde kullanılan veriler yıllık olup 1960-2018 dönemini kapsamaktadır. Analizde Türkiye ve ABD için kullanılan kişi başına GSYİH serileri Dünya Bankası'nın veri tabanından alınmıştır.

Türkiye'nin orta gelir tuzağında yer alıp almadığının tespiti için öncelikle durağanlık analizinde kullanılacak seriyi elde etmek gerekmektedir. Bu doğrultuda, Türkiye'nin kişi başına GSYIH'sinin doğal logaritmasından ABD'nin kişi başına GSYİH'sinin doğal logaritması çıkarılmıştır:

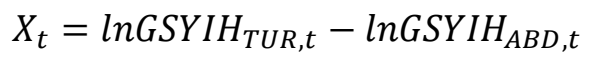

Ardından elde edilen $X_{t}$ serisine Augmented Dickey Fuller (ADF), Phillips-Perron (PP) ve Kwiatkowski-Phillips-Schmidt-Shin (KPSS) geleneksel birim kök testleri, Lumsdaine ve Papell ile Lee ve Strazicich yapısal kırılmalı birim kök testleri uygulanmıştır. Çalışmada yalnızca yapısal kırılmalı birim kök testlerinin metodolojilerine yer verilmiştir.

Serilerde iki yapısal kırılmaya olanak tanıyan Lumsdaine ve Papell (1997) testi, tek kırılmalı birim kök testlerine göre daha doğru sonuçların elde edilmesini sağlamaktadır (Yılancı, 2009: 328). Banerjee vd.'nin (1992) tek kırılmalı testine benzer bir yaklaşım üzerinden oluşturulan test, düzeyde ve trendde kırılmaya izin vermektedir. Lumsdaine ve Papell'in (1997) ortaya koyduğu model aşağıdaki biçimde ifade edilmektedir:

$$
\Delta y_{t}=\mu+\beta_{t}+\theta D U 1_{t}+\gamma D T 1_{t}+\omega D U 2_{t}+\psi D T 2_{t}+\alpha y_{t-1}+\sum_{i=1}^{k} c_{i} \Delta \mathrm{y}_{t-i}+\epsilon_{i}
$$


Burada $t=1, \ldots, T$ için, $k$. sıra gecikme polinomu $c(L)$ 'dir. $1-c(L) L$ 'nin tüm kökleri birim çemberin dışında olup, $T B 1$ ve $T B 2$ anındaki kırılmalara karşı1ık gelen kukla değişkenler $D U 1_{t}$ ve $D U 2_{t}{ }^{\prime}$ 'dir. $D T 1_{t}$ ve $D T 2_{t}$ ise trend değişimini yansıtan değişkenlerdir. Banerjee vd.'nde (1992) olduğu gibi dönüştürülmüş tahminciler $Z_{t}=\left[Z_{t}^{1}, 1,\left(y_{t}-\bar{\mu}_{0} t\right), t+\right.$ $\left.1, D U 1_{t+1}, D U 2_{t+1}, D T 1_{t+1}, D T 2_{t+1}\right]^{\prime} \quad$ olarak ifade edilmektedir. Burada $Z_{t}^{\prime}=\left(\Delta y_{t}-\right.$ $\left.\bar{\mu}_{0}, \ldots, \Delta y_{t-k+1}-\bar{\mu}_{0}\right)$ ve $\bar{\mu}_{0}=E\left(\Delta y_{t}\right)$ 'dir. Dönüştürülmüş parametre vektörü olarak tanımlanan $\Xi$ ve martingale-fark dizisi $\epsilon_{t}$ birlikte, (1) numaralı denklem aşağıdaki biçime indirgenebilir (Lumsdaine ve Papell, 1997:212-213):

$$
y_{t}=\Xi^{\prime} Z_{t-1}+\epsilon_{t}
$$

Banerjee vd.'den (1992) hareketle yazarlar aşağıdaki yakınsamaları tanımlamaktadır:

$$
T^{-1} \sum_{t=1}^{T} Z_{t-1}^{1} Z_{t-1}^{\prime} \stackrel{P}{\rightarrow} \Omega_{k}, T^{-1 / 2} \sum_{t=1}^{T} Z_{t-1}^{1} \epsilon_{t} \Rightarrow \sigma B(1), T^{-3 / 2} \sum_{t=1}^{T} Z_{t-1}^{1} y_{t} \Rightarrow 0
$$

Burada $\Omega_{k}$ rassal olmayan pozitif yar1 tanımlı matrisidir (nonrandom positive semidefinite matrix). $B(1)$ ise $k$ boyutlu, $W$ 'den bağımsız ve $\Omega_{k}$ kovaryans matrisine sahip Brownian hareketidir (Lumsdaine ve Papell, 1997:213).

Tüm $T$ gözlemleri kullanılarak tahminci ve test istatistikleri; $k_{0}=\left[T \delta_{0}\right], k_{1} \neq k_{2}, k_{1} \neq$ $k_{2} \mp 1$ ve $\delta_{0}$ başlangıç kesiri (startup fraction) olmak üzere $k_{1}=k_{0}, k_{0}+1, \ldots, T-k_{0}$ ve $k_{2}=k_{0}, k_{0}+1, \ldots, T-k_{0}$ kapsamında, $\left(k_{1}, k_{2}\right)$ farklı çift (distinct pairs) değerleri hesaplanmaktadır. Çalışma kapsamında $\delta_{0}=0.01$ olarak kullanılmıştır. $\delta_{1}$ ve $\delta_{2}$ sırasıyla $\delta_{1}=$ $T B 1 / T$ ve $\delta_{2}=T B 2 / T$ 'de meydana gelen birinci ve ikinci kırılma dönemlerinin, örnekleme bölümlenmesi ile elde edilmektedir.

(1) numaralı denklemden DU2 ve DT2 ifadelerinin çıkarılmasıyla, Zivot ve Andrews'in (1992) ortaya koydukları Model C elde edilmektedir. Ek olarak (1) numaralı denklemden DT1 ve $D U 1$ çıkarılırsa, sırasıyla söz konusu çalışmadaki Model A ve Model B elde edilmektedir. Zivot ve Andrews'in (1992) çalışmalarında kullandıkları terminoloji, Perron'un (1989) $\delta_{1}$ 'in sabit olduğu modele benzerdir (Lumsdaine ve Papell, 1997: 214). Perron'un (1989) geliştirdiği denklem sisteminde; Model A düzeyde değişime, Model B trendde değişime ve Model C ise hem düzeyde hem de trendde değişime izin vermektedir (Lee ve Strazicich, 2003:1082). Benzer bir düzenlemeyi uygulayan Lumsdaine ve Papell (1997), (1) numaralı denklemi hem düzeyde hem de trendde iki kırılmaya izin veren model CC olarak tanımlamışlardır. (1) numaralı denklemden DT2'nin çıkarılmasıyla tanımlanan Model CA ise düzeyde iki ve trendde bir kırılmaya izin vermektedir. Düzeyde iki kırılmaya izin veren Model AA ise, (1) numaralı denklemden DT1 ve DT2'nin çıkarılmasıyla elde edilmektedir. Lumsdaine ve Papell (1997) testinin boş ve alternatif hipotezleri sırasıyla yapısal kırılmaların olmadığı durumda serinin birim köklü olduğunu ve trend fonksiyonunda farklı dönemlerdeki kırılmalar ile birlikte trend durağan olduğunu varsaymaktadır (Yılanc1, 2009: 329).

Lumsdaine ve Papell (1997) yapısal kırılmalı birim kök testi, boş hipotez altında yapısal kırılmaların olmadığını varsaymaktadır. Bu nedenle boş hipotezin reddedilmesi, mutlaka birim kökün reddedilmesi anlamına gelmez; ancak yapısal kırılmasız birim kökün reddedilmesini ima edebilmektedir. Benzer şekilde alternatif hipotez ise kesin olarak yapısal kırılmalı trend durağan anlamına gelmez; ancak yapısal kırılmalı birim kökü yansıtabilmektedir (Lee ve Strazicich, 2003:1082). Bu kapsamda Lee ve Strazicich'in (2003) geliştirdikleri iki kırılmalı Lagrange çarpanı (LM) testi hem boş hem de alternatif hipotez altında kırılmalara izin vermektedir. LM testi için, veri üretme süreci modeli aşağıdaki gibi ifade edilebilir:

$$
y_{t}=\delta^{\prime} Z_{t}+e_{t}, \quad e_{t}=\beta e_{t-1}+\varepsilon_{t}
$$

Yukarıdaki denklem sisteminde $Z_{t}$ dişsal değişkenler vektörünü ifade etmekte ve $\varepsilon_{t} \sim$ iid $N\left(0, \sigma^{2}\right)$ olduğu varsayılmaktadır. Bu denklem sistemindeki iki yapısal kırılma Model A ve 
Model C üzerinden tanımlanmaktadır. Model A (crash model) düzeyde iki kırılmaya izin vermekte ve $Z_{t}=\left[1, t, D_{1 t}, D_{2 t}\right]$ olarak ifade edilmektedir. Burada $j=1,2$, için $t \geq T_{B j}+1$ iken $D_{j t}=1$ diğer durumlarda ise 0 'dır. $T_{B j}$ ise kırılmanın meydana geldiği zaman dilimini yansitmaktadır. Model $\mathrm{C}$ (trend break model) düzey ve trenddeki kırılmaları içermekte ve $Z_{t}=$ $\left[1, t, D_{1 t}, D_{2 t}, D T_{2 t}, D T_{2 t}\right]$ olarak ifade edilmektedir. Burada $j=1,2$, için $t \geq T_{B j}+1$ iken $D T_{j t}=t-T_{B j}$ olup, diğer durumlarda ise 0'dır. İki kırılmalı LM birim kök test istatistiği, LM (skor) prensibine göre aşağıdaki regresyon ile tahmin edilebilir:

$$
\Delta y_{t}=\delta^{\prime} \Delta Z_{t}+\emptyset \Delta \tilde{S}_{t-i}+u_{t}
$$

Burada $t=2, \ldots, T$ için $\tilde{S}_{t}=y_{t}-\widetilde{\Psi}_{x}-Z_{t} \tilde{\delta}$ olup, katsayılar vektörü ise $\tilde{\delta}$ ile gösterilmektedir. $\widetilde{\Psi}_{x}$ ifadesi $y_{1}-Z_{1} \tilde{\delta}$ üzerinden ortaya konmaktadır. Birim kök boş hipotezi $\Phi=0$ için tanımlanarak, LM test istatistiği aşağıdaki biçimde ifade edilmektedir:

$$
\tilde{p}=T \widetilde{\Phi},
$$

$\tilde{\tau}, \Phi=0$ için boş hipotezin t-istatistiğidir. (5) numaralı denkleme göre Model A ve Model $\mathrm{C} ; \lambda=\left(\lambda_{1}, \lambda_{1}\right)^{\prime}$ için $T \rightarrow \infty, T_{B j} / T \rightarrow \lambda_{j}$ varsayımları altında sırasıyla $Z_{t}=$ $\left[1, t, D_{1 t}, D_{2 t}\right]^{\prime}$ ve $Z_{t}=\left[1, t, D_{1 t}, D_{2 t}, D T_{2 t}, D T_{2 t}\right]$ üzerinden türetilmektedir. İki-kırılmalı minimum LM birim kök testi, kırılma noktalarını $\left(T_{B j}\right)$ bir grid araştırması kullanarak aşağıdaki gibi içsel olarak belirlenmektedir:

$$
\begin{aligned}
& L M_{p}=\inf _{\lambda} \tilde{p}(\lambda) \\
& L M_{\tau}={ }_{\lambda} \inf _{\lambda} \tilde{\tau}(\lambda)
\end{aligned}
$$

Kırılma noktaları Lumsdaine ve Papell (1997) testine benzer olarak; test istatistiklerinin minimum olduğunu nokralarda belirlenmektedir. İçsel kırılma testlerindeki olduğu gibi tipik bir şekilde, $\kappa$ için alt sınırın en küçük değeri $[\kappa, 1-\kappa]$ kırpılmaktadır. Sonrasında Zivot ve Andrews'deki (1992) bileşke fonksiyonun sürekliliği üzerine limit teorisi kullanılarak, içsel ikikırılmalı LM birim kök testlerinin asimptotik dağılımları aşağıdaki şekilde tanımlanmaktadır (Lee ve Strazicich, 2003:1083):

$$
\begin{aligned}
& L M_{p}=\inf _{\lambda}\left[-\frac{1}{2} \frac{\sigma_{\varepsilon}^{2}}{\sigma^{2}}\left(\int_{0}^{1} \underline{V}_{B}^{(m)}(r)^{2} d r\right)^{-1}\right] \\
& L M_{p}=\inf _{\lambda}\left[-\frac{1}{2} \frac{\sigma_{\varepsilon}^{2}}{\sigma^{2}}\left(\int_{0}^{1} \underline{V}_{B}^{(m)}(r)^{2} d r\right)^{-1 / 2}\right]
\end{aligned}
$$

Lee ve Strazicich (2003) LM testinin boş ve alternatif hipotezleri sırasıyla yapısal kırılmalar altında serinin birim köklü ve durağan olduğunu varsaymaktadır.

\section{BULGULAR}

Çalışmada, Türkiye genelinin yanı sıra alt bölgeler için de orta gelir tuzağı sınaması yapılması, elde edilen bulguların iki alt başlık halinde verilmesine neden olmuştur. $\mathrm{Bu}$ doğrultuda öncelikle düzey alt bölgelere ardından Türkiye geneline ilişkin bulgulara yer verilmiştir.

\subsection{Düzey Alt Bölgelerinde Orta Gelir Tuzağına İlişsin Bulgular}

Bölgeleri itibariyle homojen bir yapıya sahip olmayan Türkiye, bölgeler arası gelişmişlik farkının çok yüksek olduğu ülkelerin başında gelmektedir. Gelir dağılımındaki eşitsizliğin ekonomik büyüme önünde sorun teşkil etmesi ve orta gelir tuzağı riskini arttırması, bölgeler için orta gelir tuzağının tespitini gerekli hale getirmektedir. 
Türkiye, bölgesel politikaların belirlenmesi, karşılaştırılabilir bölgesel istatistiki verilerin oluşturulması ve bölgelerin sosyo-ekonomik analizinin yapılabilmesi amacıyla 2002 yılında istatistiki bölge birimleri sınıflandırmasını gerçekleştirmiştir. Buna göre üç kademeli bölge sistemi oluşturulmuştur. Ekonomik, coğrafi ve sosyal açıdan benzerlik taşıyan komşu iller bölgesel kalkınma planları ve demografik büyüklükleri de göz önünde bulundurularak Düzey-1 (12 bölge), Düzey-2 (26 bölge) ve Düzey-3 (81 il) bölgeleri tanımlanmıştır (Tablo 6).

Tablo 6: Türkiye'de istatistiksel bölge birimleri sınıflandırması

\begin{tabular}{|c|c|c|c|c|}
\hline Kod & $\begin{array}{c}\text { Düzey } 1 \\
\text { (12 Bölge) } \\
\end{array}$ & Kod & $\begin{array}{c}\text { Düzey } 2 \\
\text { (26 Alt Bölge) } \\
\end{array}$ & $\begin{array}{c}\text { Düzey } 3 \\
\text { (81 İl) } \\
\end{array}$ \\
\hline TR1 & İstanbul & TR10 & İstanbul alt bölgesi & İstanbul \\
\hline \multirow{3}{*}{ TR2 } & \multirow{2}{*}{ Batı Marmara } & TR21 & Tekirdağ alt bölgesi & Tekirdağ, Edirne, Kırklareli \\
\hline & & TR22 & Balıkesir alt bölgesi & Balıkesir, Çanakkale \\
\hline & & TR31 & İzmir alt bölgesi & İzmir \\
\hline \multirow[t]{2}{*}{ TR3 } & Ege & TR32 & Aydın alt bölgesi & Aydın, Denizli, Muğla \\
\hline & & TR33 & Manisa alt bölgesi & Manisa, Afyonkarahisar, Kütahya, Uşak \\
\hline \multirow{2}{*}{ TR4 } & \multirow{2}{*}{ Doğu Marmara } & TR41 & Bursa alt bölgesi & Bursa, Eskişehir, Bilecik \\
\hline & & TR42 & Kocaeli alt bölgesi & Kocaeli, Sakarya, Düzce, Bolu, Yalova \\
\hline \multirow{3}{*}{ TR5 } & \multirow{3}{*}{ Batı Anadolu } & TR51 & Ankara alt bölgesi & Ankara \\
\hline & & TR52 & Konya alt bölgesi & Konya, Karaman \\
\hline & & TR61 & Antalya alt bölgesi & Antalya, Isparta, Burdur \\
\hline \multirow[t]{2}{*}{ TR6 } & \multirow[t]{2}{*}{ Akdeniz } & TR62 & Adana alt bölgesi & Adana, Mersin \\
\hline & & TR63 & Hatay alt bölgesi & Hatay, Kahramanmaraş, Osmaniye \\
\hline \multirow[t]{3}{*}{ TR7 } & \multirow[t]{3}{*}{ Orta Anadolu } & TR71 & Kırıkkale alt bölgesi & $\begin{array}{l}\text { Kırıkkale, Aksaray, Niğde, Nevşehir, } \\
\text { Kırşehir }\end{array}$ \\
\hline & & TR72 & Kayseri alt bölgesi & Kayseri, Sivas, Yozgat \\
\hline & & TR81 & Zonguldak alt bölgesi & Zonguldak, Karabük, Bartın \\
\hline \multirow[t]{2}{*}{ TR8 } & \multirow[t]{2}{*}{ Batı Karadeniz } & TR82 & Kastamonu alt bölgesi & Kastamonu, Çankırı, Sinop \\
\hline & & TR83 & Samsun alt bölgesi & Samsun, Tokat, Çorum, Amasya \\
\hline TR9 & Doğu Karadeniz & TR90 & Trabzon alt bölgesi & $\begin{array}{l}\text { Trabzon, Ordu, Giresun, Rize, Artvin, } \\
\text { Gümüşhane }\end{array}$ \\
\hline \multirow{2}{*}{ TRA } & \multirow{2}{*}{$\begin{array}{l}\text { Kuzeydoğu } \\
\text { Anadolu }\end{array}$} & TRA1 & Erzurum alt bölgesi & Erzurum, Erzincan, Bayburt \\
\hline & & TRA2 & Ağr1 alt bölgesi & Ağr1, Kars, Iğdır, Ardahan \\
\hline \multirow{2}{*}{ TRB } & \multirow{2}{*}{$\begin{array}{l}\text { Ortadoğu } \\
\text { Anadolu }\end{array}$} & TRB1 & Malatya alt bölgesi & Malatya, Elazı̆̆, Bingöl, Tunceli \\
\hline & & TRB2 & Van alt bölgesi & Van, Muş, Bitlis, Hakkari \\
\hline \multirow{3}{*}{ TRC } & \multirow{3}{*}{$\begin{array}{l}\text { Güneydoğu } \\
\text { Anadolu }\end{array}$} & TRC1 & Gaziantep alt bölgesi & Gaziantep, Adiyaman, Kilis \\
\hline & & TRC2 & Şanlıurfa alt bölgesi & Şanlıurfa, Diyarbakır \\
\hline & & TRC3 & Mardin alt bölgesi & Mardin, Batman, Şırnak, Siirt \\
\hline
\end{tabular}

Kaynak: Kalkınma Bakanlığı,

(http://www3.kalkinma.gov.tr/PortalDesign/PortalControls/WebIcerikGosterim.aspx ?Enc=83D5A6FF03C7B4FCC26 F032470459B0B, Erişim Tarihi: 02.09.2019) 
Yeldan vd. (2012) çalışmalarında, orta gelir tuzağı olgusunun incelenmesinde ülkenin alt bölgelerinin gelir düzeylerinin ve üretim yapılarının dikkate alınması gerektiğine vurgu yapmışlardır. "İyimser" olarak nitelendirdikleri Felipe vd.'nin (2012) zaman eşikleri yöntemini kullanarak 2004-2011 dönemi için düzey-2 alt bölgelerinde orta gelir tuzağının var olup olmadığını incelemişlerdir. Buna göre 2011 yılında sadece 7 düzey-2 alt bölgesinin orta gelir tuzağı riski taşımadığını tespit etmişlerdir. Çalışmamızda, Yeldan vd.'nin (2012) analizini 20042017 dönemi için genişlettiğimizde orta gelir tuzağı riski olmayan bölge sayısının 2017 itibariyle 5 'e düştüğü görülmektedir. Şekil 1'den de görüleceği üzere risk teşkil eden bölge sayısındaki azalmanın gelir düzeyindeki artıştan ziyade azalıştan kaynaklandığı görülmektedir.

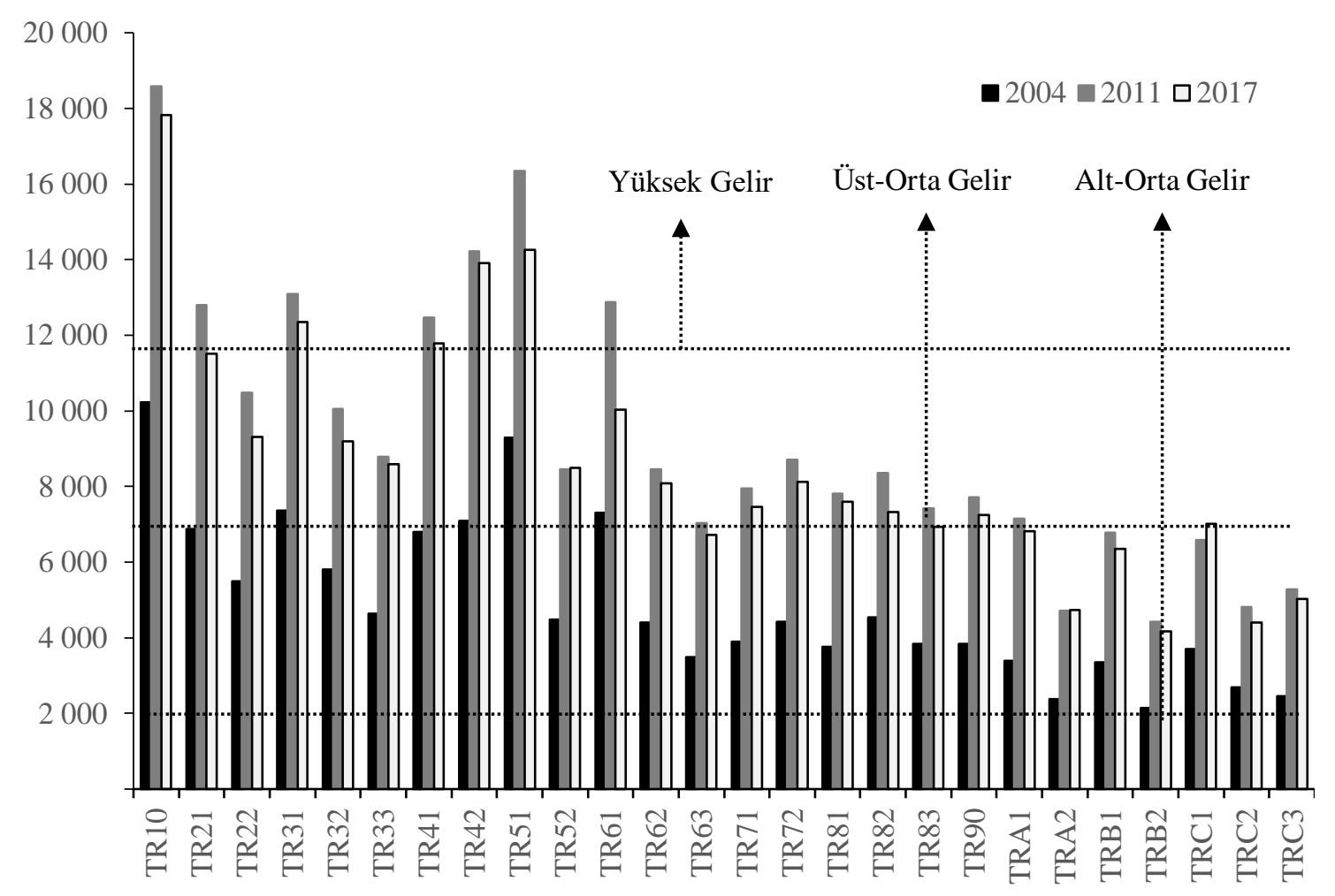

Şekil 1: Düzey-2 Alt Bölgelerinde Kişi Başına GSYİH (\$)

Kaynak: TÜIK, (http://www.tuik.gov.tr/UstMenu.do?metod=temelist, Erişim Tarihi: 19.08.2019)

Orta gelir tuzağının varlığının farklı bir yöntemle tespit edildiği Woo'nun (2012) yakalama endeksi yaklaşımı düzey-2 alt bölgeleri için ele alındığında benzer sonuçların ortaya çıktığı görülmektedir (Tablo 7). 2011 yılı itibariyle 9 bölgenin orta gelir grubunda yer aldığ 1 ve orta gelir tuzağı riski taşıdığ 1 görülürken 2017 yılında bu rakamın 5'e düştüğü görülmektedir. 2017 y1lı itibariyle orta gelir grubunda yer alan bölge sayıs1 2005 yılındaki seviyeye gerilemiştir. Uzun bir süre orta gelir grubunda yer alan TR21 alt bölgesi (Tekirdağ, Edirne ve Kırklareli) ve TR61 alt bölgesi (Antalya, Isparta ve Burdur) Woo'nun (2012) yöntemine göre düşük gelir grubuna düşmüştür. Bununla birlikte orta gelir grubunda yer alan ülkelerin CUI değerlerinde kayda değer bir düşüş olduğu görülmektedir. 
Tablo 7: Düzey-2 Alt Bölgelerinin CUI Değerleri

\begin{tabular}{|c|c|c|c|c|c|c|c|c|c|c|c|c|c|c|}
\hline & 2004 & 2005 & 2006 & 2007 & 2008 & 2009 & 2010 & 2011 & 2012 & 2013 & 2014 & 2015 & 2016 & 2017 \\
\hline TR10 & 0.24 & 0.28 & 0.29 & 0.34 & 0.38 & 0.32 & 0.36 & 0.37 & 0.37 & 0.39 & 0.36 & 0.32 & 0.32 & 0.30 \\
\hline TR21 & 0.16 & 0.19 & 0.19 & 0.22 & 0.25 & 0.21 & 0.25 & 0.26 & 0.25 & 0.26 & 0.25 & 0.21 & 0.21 & 0.19 \\
\hline TR22 & 0.13 & 0.15 & 0.15 & 0.18 & 0.21 & 0.18 & 0.21 & 0.21 & 0.21 & 0.21 & 0.20 & 0.17 & 0.17 & 0.16 \\
\hline TR31 & 0.18 & 0.20 & 0.21 & 0.24 & 0.27 & 0.22 & 0.25 & 0.26 & 0.27 & 0.28 & 0.26 & 0.22 & 0.22 & 0.21 \\
\hline TR32 & 0.14 & 0.15 & 0.16 & 0.18 & 0.20 & 0.17 & 0.20 & 0.20 & 0.20 & 0.21 & 0.20 & .17 & 0.16 & 0.15 \\
\hline TR33 & 0.11 & 0.13 & 0.13 & 0.15 & 0.18 & 0.16 & 0.17 & 0.18 & 0.19 & 0.19 & 0.18 & 0.16 & 0.15 & 0.14 \\
\hline TR41 & 0.16 & 0.19 & 0.20 & 0.23 & 0.26 & 0.21 & 0.24 & 0.25 & & 0.27 & 0.25 & 0.22 & & 0.20 \\
\hline TR42 & 0.17 & 0.20 & 0.21 & 0.25 & 0.28 & 0.23 & 0.26 & & & 0.31 & & 0.25 & & 0.23 \\
\hline TR51 & 0.22 & 0.26 & 0.27 & 0.32 & 0.36 & 0.30 & 0.33 & 0.33 & 0.32 & 0.33 & 0.31 & 0.27 & 0.26 & 0.24 \\
\hline TR52 & 0.11 & 0.12 & 0.13 & 0.15 & 0.17 & 0.15 & 0.16 & 0.17 & 0.17 & 0.19 & 0.18 & 0.16 & 0.15 & 0.14 \\
\hline TR61 & 0.17 & 0.20 & 0.20 & 0.24 & 0.26 & 0.22 & 0.26 & 0.26 & 0.25 & 0.25 & 0.23 & 0.20 & 0.18 & 0.17 \\
\hline TR62 & 0.11 & 0.12 & 0.13 & 0.15 & 0.17 & 0.14 & 0.17 & 0.17 & 0.17 & 0.18 & 0.17 & 0.15 & 0.15 & 0.14 \\
\hline TR63 & 0.08 & 0.10 & 0.10 & 0.12 & 0.13 & 0.11 & 0.14 & 0.14 & 0.14 & 0.14 & 0.14 & 0.12 & 0.12 & 0.11 \\
\hline TR71 & 0.09 & 0.11 & 0.11 & 0.13 & 0.14 & 0.13 & 0.15 & 0.16 & 0.15 & 0.16 & 0.15 & 0.14 & 0.13 & 0.13 \\
\hline TR72 & 0.11 & 0.12 & 0.13 & 0.15 & 0.17 & 0.14 & 0.17 & 0.17 & 0.18 & 0.18 & 0.17 & 0.15 & 0.15 & 0.14 \\
\hline TR81 & 0.09 & 0.11 & 0.11 & 0.13 & & 0.12 & 0.14 & 0.16 & & 0.17 & & 0.14 & & 0.13 \\
\hline TR82 & 0.11 & 0.12 & 0.12 & 0.14 & 0.16 & 0.14 & 0.16 & 0.17 & 0.17 & 0.17 & 0.16 & 0.14 & 0.14 & 0.12 \\
\hline TR83 & 0.09 & 0.11 & 0.11 & 0.13 & 0.15 & 0.13 & 0.15 & 0.15 & 0.15 & 0.16 & 0.15 & 0.13 & 0.13 & 0.12 \\
\hline TR90 & 0.09 & 0.11 & 0.12 & 0.14 & 0.16 & 0.13 & 0.15 & 0.15 & 0.16 & 0.16 & 0.16 & 0.14 & 0.13 & 0.12 \\
\hline TRA1 & 0.08 & 0.09 & 0.09 & 0.11 & 0.13 & 0.12 & 0.14 & 0.14 & 0.15 & 0.15 & 0.14 & 0.12 & 0.12 & 0.11 \\
\hline TRA2 & 0.06 & 0.06 & 0.07 & 0.08 & 0.08 & 0.08 & 0.10 & 0.09 & 0.10 & 0.10 & 0.09 & 0.08 & 0.08 & 0.08 \\
\hline TRB1 & 0.08 & 0.10 & 0.10 & 0.12 & 0.13 & 0.11 & 0.13 & 0.14 & 0.14 & 0.14 & 0.13 & 0.12 & 0.12 & 0.11 \\
\hline TRB2 & 0.05 & 0.06 & 0.06 & 0.07 & 0.08 & 0.07 & 0.09 & 0.09 & 0.10 & 0.10 & 0.09 & 0.08 & 0.08 & 0.07 \\
\hline TRC1 & 0.09 & 0.10 & 0.10 & 0.12 & 0.13 & 0.11 & 0.13 & 0.13 & 0.13 & 0.15 & 0.14 & 0.13 & 0.13 & 0.12 \\
\hline TRC2 & 0.06 & 0.07 & 0.07 & 0.08 & 0.09 & 0.08 & 0.10 & 0.10 & 0.10 & 0.10 & 0.09 & 0.08 & 0.08 & 0.07 \\
\hline TRC3 & 0.06 & 0.07 & 0.07 & 0.08 & 0.09 & 0.08 & 0.10 & 0.11 & 0.11 & 0.11 & 0.10 & 0.09 & 0.09 & 0.08 \\
\hline
\end{tabular}

Kaynak: TÜİK ve Dünya Bankası verileri kullanılarak yazarlar tarafından hesaplanmıştır. 
Tablo 8: Düzey-3 İllerinin CUI Değerleri

\begin{tabular}{|c|c|c|c|c|c|c|c|c|c|c|c|c|c|c|}
\hline & 2004 & 2005 & 2006 & 2007 & 2008 & 2009 & 2010 & 2011 & 2012 & 2013 & 2014 & 2015 & 2016 & 2017 \\
\hline Adana & 9.96 & 11.65 & 11.93 & 14.13 & 15.77 & 13.78 & 16.14 & 16.21 & 16.52 & 17.20 & 16.20 & 14.16 & 13.87 & 12.99 \\
\hline Adıyaman & 6.23 & 7.26 & 7.48 & 8.80 & 10.17 & 8.52 & 1.01 & 10.37 & 10.29 & 11.45 & 11.33 & 9.77 & 9.36 & 8.61 \\
\hline $\begin{array}{l}\text { Afyonkarah } \\
\text { isar }\end{array}$ & 9.37 & 10.69 & 11.03 & 13.14 & 15.02 & 13.12 & 15.42 & 15.40 & 15.23 & 15.83 & 15.23 & 13.43 & 13.08 & 11.84 \\
\hline Ăğrı & 4.61 & 5.30 & 5.03 & 5.86 & 6.33 & 5.80 & 7.82 & 7.32 & 7.64 & 7.79 & 7.09 & 6.31 & 6.39 & 5.86 \\
\hline Amasya & 10.14 & 11.81 & 11.73 & 13.36 & 16.37 & 14.73 & 16.30 & 16.49 & 16.80 & 17.57 & 15.81 & 14.60 & 14.05 & 12.80 \\
\hline Ankara & 22.19 & 25.77 & 26.63 & 32.22 & 35.82 & 30.40 & 33.03 & 32.82 & 31.72 & 33.33 & 30.66 & 26.56 & 25.99 & 23.94 \\
\hline Antalya & 19.48 & 21.83 & 22.57 & 26.27 & 28.40 & 23.68 & 28.08 & 28.06 & 26.48 & 26.97 & 24.82 & 21.56 & 18.90 & 17.68 \\
\hline Artvin & 10.96 & 12.95 & 14.14 & 16.82 & 19.73 & 16.41 & 19.57 & 19.10 & 19.40 & 19.83 & 18.39 & 16.28 & 15.78 & 14.96 \\
\hline Aydın & 11.54 & 12.73 & 13.62 & 14.80 & 16.49 & 13.90 & 16.12 & 16.32 & 16.48 & 16.99 & 15.98 & 13.90 & 13.55 & 12.92 \\
\hline Balıkesir & 12.59 & 14.80 & 14.78 & 17.40 & 20.12 & 17.72 & 19.83 & 19.87 & 19.54 & 19.58 & 18.56 & 15.78 & 15.75 & 14.79 \\
\hline Bilecik & 16.44 & 20.09 & 21.00 & 25.71 & 29.30 & 24.17 & 25.61 & 26.42 & 27.66 & 29.84 & 27.26 & 23.18 & 21.98 & 19.90 \\
\hline Bingöl & 5.49 & 6.64 & 6.56 & 8.04 & 9.15 & 8.14 & 9.80 & 10.13 & 10.64 & 11.26 & 10.71 & 9.59 & 9.60 & 8.84 \\
\hline Bitlis & 5.01 & 5.87 & 6.12 & 7.53 & 8.43 & 7.27 & 8.60 & 9.15 & 9.80 & 10.89 & 10.09 & 8.59 & 8.12 & 7.15 \\
\hline Bolu & 16.63 & 19.47 & 19.98 & 22.97 & 26.21 & 22.47 & 25.36 & 26.28 & 25.89 & 27.22 & 25.64 & 21.94 & 20.34 & 18.51 \\
\hline Burdur & 13.31 & 15.39 & 15.73 & 18.40 & 20.96 & 18.32 & 21.07 & 20.73 & 20.42 & 20.60 & 19.51 & 17.08 & 16.34 & 14.59 \\
\hline Bursa & 16.55 & 19.40 & 20.17 & 23.71 & 26.25 & 21.46 & 20.40 & 25.23 & 25.14 & 26.59 & 25.03 & 21.87 & 21.12 & 20.01 \\
\hline Çanakkale & 14.30 & 16.81 & 17.03 & 20.18 & 22.88 & 19.26 & 23.44 & 23.85 & 23.38 & 23.45 & 22.27 & 19.09 & 18.87 & 17.63 \\
\hline Çankırı & 10.85 & 12.20 & 11.81 & 13.96 & 16.15 & 13.94 & 15.79 & 16.52 & 16.45 & 16.96 & 15.91 & 14.36 & 14.25 & 12.49 \\
\hline Çorum & 9.31 & 10.45 & 10.40 & 12.21 & 14.70 & 12.70 & 15.20 & 15.15 & 14.74 & 15.22 & 14.28 & 12.68 & 1.24 & 11.46 \\
\hline Denizli & 14.64 & 15.85 & 16.67 & 18.87 & 20.50 & 16.66 & 19.54 & 20.68 & 20.57 & 21.71 & 20.71 & 17.52 & 17.34 & 16.46 \\
\hline Diyarbakir & 6.91 & 7.66 & 7.97 & 9.28 & 10.02 & 8.81 & 10.41 & 10.74 & 10.85 & 11.43 & 10.70 & 9.34 & 9.08 & 8.40 \\
\hline Edirne & 12.26 & 14.18 & 14.15 & 16.85 & 19.55 & 16.99 & 20.50 & 20.04 & 19.93 & 20.42 & 19.52 & 16.58 & 15.97 & 14.53 \\
\hline Elazığ & 8.52 & 10.08 & 10.55 & 12.73 & 14.39 & 12.58 & 14.60 & 14.68 & 14.94 & 15.36 & 14.17 & 12.48 & 12.11 & 11.21 \\
\hline Erzincan & 11.18 & 12.64 & 13.01 & 15.61 & 18.16 & 16.43 & 19.05 & 20.02 & 21.29 & 21.35 & 19.18 & 15.95 & 15.62 & 14.73 \\
\hline Erzurum & 7.29 & 8.19 & 8.44 & 10.09 & 11.69 & 10.75 & 12.82 & 12.87 & 12.89 & 13.59 & 12.91 & 11.41 & 11.39 & 10.65 \\
\hline Eskişehir & 15.03 & 17.95 & 18.76 & 22.16 & 24.74 & 20.76 & 23.26 & 24.04 & 24.23 & 20.61 & 20.41 & 20.95 & 20.22 & 18.71 \\
\hline Gaziantep & 10.02 & 11.29 & 11.60 & 13.12 & 14.36 & 11.94 & 13.76 & 14.41 & 14.47 & 16.14 & 15.71 & 14.19 & 13.66 & 12.86 \\
\hline Giresun & 7.75 & 10.12 & 10.17 & 11.51 & 13.77 & 11.49 & 13.34 & 13.19 & 13.38 & 13.53 & 12.51 & 12.64 & 10.89 & 10.24 \\
\hline Gümüşhane & 9.70 & 10.89 & 11.10 & 13.30 & 14.93 & 13.14 & 15.67 & 16.54 & 16.25 & 16.74 & 15.35 & 12.75 & 11.21 & 9.63 \\
\hline Hakkari & 6.30 & 7.17 & 7.36 & 8.98 & 9.78 & 8.41 & 9.69 & 9.46 & 9.88 & 10.34 & 9.75 & 8.39 & 8.67 & 8.20 \\
\hline Hatay & 8.64 & 10.21 & 10.36 & 12.27 & 13.84 & 11.54 & 13.95 & 14.69 & 14.25 & 14.88 & 13.96 & 12.40 & 12.30 & 11.90 \\
\hline Isparta & 12.05 & 13.81 & 14.06 & 16.54 & 18.82 & 16.54 & 17.79 & 18.68 & 18.55 & 18.53 & 17.53 & 14.82 & 15.19 & 13.72 \\
\hline Mersin & 11.19 & 13.17 & 13.52 & 15.99 & 18.14 & 15.30 & 17.73 & 17.91 & 18.19 & 18.53 & 17.74 & 15.75 & 15.43 & 14.34 \\
\hline İstanbul & 24.41 & 28.05 & 28.95 & 34.24 & 38.47 & 32.31 & 36.13 & 37.33 & 37.36 & 39.27 & 36.49 & 32.50 & 31.55 & 29.95 \\
\hline İzmir & 17.55 & 20.11 & 21.04 & 24.22 & 26.76 & 22.13 & 25.20 & 26.30 & 26.54 & 27.84 & 26.07 & 22.37 & 21.72 & 20.74 \\
\hline Kars & 6.26 & 6.82 & 7.21 & 8.52 & 9.37 & 8.62 & 10.75 & 10.77 & 11.08 & 10.85 & 10.39 & 9.96 & 9.64 & 9.34 \\
\hline Kastamonu & 11.42 & 12.28 & 12.21 & 14.86 & 16.88 & 14.74 & 17.14 & 17.67 & 17.53 & 17.64 & 16.65 & 14.41 & 13.93 & 12.98 \\
\hline Kayseri & 12.69 & 15.07 & 15.46 & 18.10 & 19.91 & 16.36 & 18.70 & 19.65 & 19.72 & 20.89 & 19.34 & 16.65 & 16.19 & 15.21 \\
\hline Kırklareli & 14.71 & 17.04 & 17.25 & 20.60 & 23.39 & 20.31 & 24.56 & 24.42 & 24.46 & 25.04 & 23.30 & 19.84 & 19.13 & 17.78 \\
\hline Kırşehir & 9.24 & 11.20 & 10.71 & 1.25 & 14.03 & 12.85 & 16.07 & 16.48 & 15.79 & 16.01 & 14.73 & 13.00 & 13.01 & 12.65 \\
\hline Kocaeli & 20.97 & 24.86 & 26.78 & 31.84 & 35.94 & 28.16 & 33.08 & 36.32 & 35.89 & 38.98 & 36.38 & 31.87 & 30.59 & 29.77 \\
\hline Konya & 10.43 & 12.10 & 12.36 & 14.57 & 16.41 & 14.51 & 15.93 & 16.85 & 16.59 & 18.09 & 17.54 & 15.45 & 14.91 & 14.02 \\
\hline Kütahya & 9.73 & 11.50 & 11.89 & 14.31 & 17.32 & 14.79 & 16.64 & 16.98 & 16.90 & 17.50 & 16.55 & 14.43 & 13.99 & 13.11 \\
\hline Malatya & 8.18 & 10.33 & 9.66 & 11.47 & 12.86 & 11.36 & 12.89 & 13.45 & 13.35 & 13.74 & 12.71 & 11.69 & 11.28 & 11.04 \\
\hline
\end{tabular}




\begin{tabular}{|c|c|c|c|c|c|c|c|c|c|c|c|c|c|c|}
\hline & 2004 & 2005 & 2006 & 2007 & 2008 & 2009 & 2010 & 2011 & 2012 & 2013 & 2014 & 2015 & 2016 & 2017 \\
\hline Manisa & 12.66 & 15.38 & 15.74 & 17.60 & 20.42 & 17.45 & 18.61 & 18.79 & 21.13 & 21.32 & 20.32 & 17.85 & 17.43 & 16.28 \\
\hline $\begin{array}{l}\text { Kahraman } \\
\text { maraş }\end{array}$ & 8.55 & 9.95 & 9.21 & 11.27 & 13.01 & 11.50 & 13.64 & 13.58 & 13.42 & 14.13 & 13.18 & 11.70 & 11.23 & 10.57 \\
\hline Mardin & 5.61 & 6.55 & 6.93 & 8.06 & 9.06 & 8.14 & 10.51 & 10.64 & 11.13 & 11.76 & 11.11 & 9.96 & 9.58 & 9.10 \\
\hline Muğla & 15.84 & 18.41 & 19.30 & 21.79 & 23.94 & 20.42 & 23.91 & 24.31 & 23.78 & 24.24 & 22.62 & 19.57 & 18.39 & 17.25 \\
\hline Muş & 5.55 & 6.65 & 6.60 & 7.65 & 8.73 & 8.02 & 9.92 & 10.18 & 10.65 & 10.89 & 9.81 & 8.46 & 8.18 & 7.43 \\
\hline Nevşehir & 10.83 & 11.46 & 11.25 & 13.41 & 15.05 & 13.08 & 16.29 & 16.73 & 15.78 & 16.66 & 15.87 & 14.22 & 1.32 & 11.94 \\
\hline Niğde & 9.20 & 10.51 & 10.19 & 12.23 & 13.49 & 11.95 & 14.06 & 14.92 & 14.79 & 15.02 & 14.62 & 13.48 & 12.42 & 11.51 \\
\hline Ordu & 7.33 & 9.47 & 9.69 & 11.27 & 12.63 & 10.48 & 12.06 & 12.10 & 12.38 & 12.73 & 12.19 & 12.58 & 10.59 & 10.07 \\
\hline Rize & 10.68 & 12.52 & 13.22 & 15.44 & 17.22 & 15.17 & 17.89 & 17.99 & 18.91 & 19.51 & 18.67 & 16.32 & 15.80 & 14.80 \\
\hline Sakarya & 12.84 & 14.94 & 15.74 & 18.15 & 20.44 & 16.98 & 19.37 & 20.06 & 20.44 & 21.56 & 20.36 & 18.29 & 17.51 & 16.72 \\
\hline Samsun & 9.69 & 11.37 & 11.87 & 13.69 & 16.05 & 13.49 & 15.63 & 15.81 & 16.39 & 17.07 & 16.07 & 14.38 & 13.68 & 12.56 \\
\hline Siirt & 4.99 & 6.05 & 6.32 & 7.31 & 8.38 & 8.11 & 9.90 & 10.37 & 10.64 & 11.13 & 10.23 & 8.53 & 8.29 & 7.65 \\
\hline Sinop & 9.70 & 10.69 & 10.76 & 12.70 & 14.41 & 12.53 & 14.80 & 15.39 & 15.56 & 16.16 & 14.32 & 12.32 & 12.17 & 10.88 \\
\hline Sivas & 8.92 & 10.15 & 10.46 & 12.25 & 14.25 & 12.78 & 15.42 & 16.20 & 16.38 & 16.86 & 15.45 & 13.60 & 13.30 & 12.37 \\
\hline Tekirdağ & 19.77 & 22.17 & 22.00 & 25.99 & 28.56 & 23.36 & 27.44 & 28.96 & 28.39 & 29.69 & 27.80 & 23.82 & 23.02 & 21.86 \\
\hline Tokat & 7.50 & 8.54 & 8.72 & 10.21 & 12.21 & 10.73 & 12.24 & 12.08 & 12.48 & 12.78 & 11.78 & 10.84 & 10.27 & 9.29 \\
\hline Trabzon & 10.65 & 12.81 & 13.38 & 15.76 & 17.76 & 15.31 & 17.66 & 17.95 & 18.40 & 19.40 & 18.45 & 16.28 & 15.64 & 14.18 \\
\hline Tunceli & 10.84 & 12.45 & 12.52 & 15.11 & 16.71 & 15.47 & 19.46 & 19.00 & 18.90 & 19.86 & 18.64 & 16.17 & 16.43 & 15.58 \\
\hline Şanlıurfa & 5.91 & 6.64 & 6.63 & 7.47 & 8.28 & 7.03 & 8.89 & 8.71 & 8.59 & 8.80 & 8.17 & 7.35 & 6.98 & 6.53 \\
\hline Uşak & 10.65 & 11.84 & 12.16 & 14.10 & 16.95 & 14.74 & 17.47 & 18.69 & 18.89 & 19.64 & 18.32 & 15.41 & 15.24 & 15.45 \\
\hline Van & 4.64 & 5.59 & 5.67 & 6.78 & 7.72 & 6.67 & 7.84 & 8.12 & 9.05 & 9.23 & 8.29 & 6.89 & 7.11 & 6.48 \\
\hline Yozgat & 8.01 & 9.21 & 8.97 & 10.68 & 12.10 & 11.05 & 13.19 & 13.46 & 13.05 & 13.86 & 13.12 & 11.86 & 11.71 & 10.54 \\
\hline Zonguldak & 8.55 & 10.17 & 10.64 & 12.91 & 14.09 & 11.78 & 14.14 & 15.32 & 15.05 & 16.30 & 15.42 & 13.34 & 13.25 & 12.74 \\
\hline Aksaray & 8.32 & 9.87 & 9.98 & 12.05 & 13.61 & 12.13 & 14.48 & 14.64 & 14.33 & 15.12 & 15.24 & 13.85 & 13.02 & 12.26 \\
\hline Bayburt & 7.80 & 8.56 & 8.73 & 10.69 & 11.37 & 10.89 & 13.41 & 12.93 & 14.08 & 14.68 & 13.25 & 11.72 & 11.16 & 9.78 \\
\hline Karaman & 12.88 & 15.07 & 14.07 & 17.82 & 20.13 & 17.45 & 16.98 & 17.96 & 19.71 & 22.05 & 20.44 & 18.11 & 16.87 & 16.27 \\
\hline Kırıkkale & 9.18 & 11.41 & 11.94 & 13.73 & 16.15 & 13.74 & 16.25 & 17.80 & 17.30 & 18.20 & 16.38 & 14.52 & 13.87 & 14.68 \\
\hline Batman & 6.79 & 7.86 & 8.12 & 9.16 & 10.72 & 8.80 & 11.00 & 11.29 & 10.85 & 10.87 & 9.86 & 8.21 & 8.05 & 7.80 \\
\hline Şırnak & 6.02 & 6.72 & 6.97 & 8.30 & 9.15 & 8.33 & 9.68 & 9.90 & 10.57 & 11.28 & 10.19 & 9.08 & 9.04 & 8.69 \\
\hline Bartın & 9.07 & 10.49 & 10.53 & 12.33 & 13.57 & 11.62 & 13.57 & 14.40 & 14.88 & 15.51 & 14.44 & 12.54 & 12.19 & 11.11 \\
\hline Ardahan & 6.84 & 6.85 & 7.60 & 9.30 & 10.29 & 9.50 & 12.97 & 12.49 & 13.16 & 12.71 & 11.63 & 11.56 & 11.35 & 10.72 \\
\hline Iğdır & 7.06 & 8.65 & 9.25 & 10.47 & 12.12 & 10.62 & 12.03 & 11.86 & 12.84 & 12.66 & 11.48 & 10.57 & 10.01 & 10.24 \\
\hline Yalova & 14.20 & 16.04 & 16.85 & 20.21 & 22.00 & 19.06 & 21.49 & 23.83 & 23.08 & 24.34 & 20.38 & 21.07 & 20.61 & 19.39 \\
\hline Karabük & 10.04 & 11.60 & 12.43 & 14.63 & 16.85 & 13.88 & 16.03 & 17.80 & 17.25 & 18.56 & 17.61 & 15.19 & 14.74 & 14.12 \\
\hline Kilis & 6.81 & 8.95 & 8.65 & 10.33 & 10.61 & 10.03 & 12.07 & 10.44 & 10.86 & 12.94 & 11.41 & 11.42 & 10.67 & 10.16 \\
\hline Osmaniye & 6.81 & 8.08 & 8.11 & 10.01 & 11.72 & 10.00 & 13.43 & 13.66 & 13.20 & 13.87 & 13.27 & 11.39 & 11.35 & 10.94 \\
\hline Düzce & 11.81 & 13.51 & 14.61 & 17.30 & 19.77 & 16.08 & 18.50 & 19.08 & 20.00 & 20.74 & 20.09 & 18.39 & 17.09 & 10.56 \\
\hline
\end{tabular}

Kaynak: TÜIK ve Dünya Bankası verileri kullanılarak yazarlar tarafından hesaplanmıştır.

Yakalama endeksi yaklaşımı, orta gelir tuzağı tespitinin iller bazında da yapılabilmesine olanak sağlayan bir yaklaşımdır. Bu doğrultuda çalışmada, 81 düzey-3 ilinin CUI değerleri hesaplanmıştır (Tablo 8). Buna göre, 2000'li yılların ikinci yarısında orta gelir grubuna yükselen çok sayıdaki ilin 2014 yılından itibaren düşük gelir grubunda yer aldığı görülmektedir. Diğer bir ifadeyle, orta gelir grubundaki il sayısındaki azalmanın yüksek gelir grubuna doğru yakınsamadan ziyade ıraksamadan kaynaklandığını ifade etmek mümkündür. 
CUI değerlerinin küresel konjonktürdeki gelişmelerle aynı yönde değişim gösterdiği görülmektedir. 2013 yılının ikinci yarısından itibaren küresel likidite koşullarının sıkılaşmaya başlaması ve bir dizi iç ve dış şoka maruz kalınması, yabancı sermaye yatırımlarını olumsuz etkilemiştir. Büyümedeki yavaşlamanın temel gerekçelerinden biri olan bu durum, sanayi sektöründeki üretim süreçlerinde ithal girdiye olan bağımlılığın devam ettiğini yansıtmaktadır. Diğer bir ifadeyle sanayi sektörü üretim süreçlerinde kullanılan girdilerin birçoğunun yurtiçi arzını gerçekleştirememektedir.

Bölgelere/illere ilişkin CUI değerlerinin seyrini, Ohno'nun (2009) ekonomik gelişme evreleri yaklaşımında ifade edilen argümanlarla açıklamak mümkündür. Ohno'ya (2009) göre, orta gelir tuzağından kurtulabilmenin en önemli koşullarından biri içsel değerin yurt içerisinde yaratılmasıdır. Buna karşın diğer bölgelere nispeten sanayi sektörü hasılası daha fazla olan batı bölgelerindeki/illerindeki CUI değerleri -özellikle 2014 yılından itibaren- düşüş göstermiştir. Bu durum, sanayi sektörünün küresel likidite koşullarına ve yabancı sermaye yatırımlarına olan hassasiyetin devam ettiğine işaret etmektedir. Aynı zamanda, sanayi sektöründe orta ve yüksek teknolojili üretimi destekleyecek arz yanlı politikaların uygulanmadığını veya uygulamaların arzu edilen sonuçları vermediğini de yansıtmaktadır. Bu bağlamda sanayi sektörünün, içsel değeri yurt içerisinde yaratacak ve yüksek gelir grubuna doğru sıçramayı yapacak yapısal dönüşümü henüz tamamlayamadığını ifade etmek mümkündür.

Egawa'ya (2013) göre gelir dağılımındaki eşitsizlik, ekonomik büyümenin önündeki en önemli engellerden biridir. Çalışmada, hesaplanan CUI değerleri, bölgeler ve iller arasında keskin gelir farklılıklarının olduğuna işaret etmektedir. Kırsal nüfusun ağırlığının fazla olduğu doğu bölgeleri/illeri, kişi başına gelirin yükselme trendine girdiği dönemlerde dahi orta gelir grubundan çok uzakta bir seyir izlemiştir.

Doğu bölgelerinin/illerinin ekonomileri temelde tarıma dayanmakta ve beşeri sermayesinin niteliği orta ve yüksek teknolojili üretim süreçlerine katılımı sağlayacak düzeyde değildir. Dolayısıyla ekonomik gelişmenin ilk aşamalarında yer alan bu bölgeleri/illeri sanayi sektörü temelli kalkındırma faaliyetlerinin ve sanayi sektörü yatırımlarının, beşeri sermayeye ilişkin problemler yaşaması kuvvetle muhtemeldir. Bunun yerine Yeldan vd.'nin (2012) de ifade ettiği gibi bu bölgelerde, öncelikli olarak tarım sektöründe endüstriyel üretime geçilmesine öncülük edecek kurumsal yapıların oluşturulması ve güçlendirilmesi gerekmektedir. Bir sonraki süreçte, sanayi üretimine geçişe yönelik adımlar atılmalıdır. Bununla birlikte sanayi üretimine yönelik faaliyetler de fiziki sermaye yatırımları ile sınırlı kalmamalı, beşeri sermayenin niteliğinin geliştirilmesine yönelik faaliyetler ile eş anlı yürütülmelidir.

\subsection{Türkiye Genelinde Orta Gelir Tuzağına İlişkin Bulgular}

Türkiye ekonomisi için orta gelir tuzağının tespitine ilişkin olarak Robertson ve Ye'nin (2013) yönteminden hareketle geleneksel ve yapısal kırılmalı birim kök testleri uygulanmıştır. Birim kök testine tabi tutulacak serinin hesaplanmasında ise daha önce de belirtildiği gibi, Türkiye ve ABD'nin GSYİH'lerinin doğal logaritmalarının farkları alınmıştır. $X_{t}$ değişkeni olarak adlandırılan fark serisinin, hem düzey değerinde hem de birinci farkı alınarak, birim kök testlerine tabi tutulmuştur.

Aşağıdaki Tablo 9'da geleneksel birim kök testlerinin sonuçları yer almaktadır. ADF ve PP birim kök testi için sabit, sabit ile trend içeren ve sabit ile trend içermeyen modellerin sonuçlarına göre $X_{t}$ serisi düzey değerinde durağan olmayıp, birim kök içermektedir. Diğer taraftan boş hipotezi serinin birim kök içermediğini ifade eden KPSS testine göre sabit, sabit ve trend içeren modellerde, boş hipotez reddedilerek serinin birim kök içerdiği ve durağan olmadığ tespit edilmiştir. Geleneksel birim kök testlerinin sonuçlarına göre, $X_{t}$ serisi düzey değerinde birim kök içermektedir. $X_{t}$ serisinin birinci farkı alınarak elde edilen $\Delta X_{t}$, ADF ve PP birim kök 
testinde sabit, sabit ile trend içeren ve sabit ile trend içermeyen modellerde \%1 anlaml1lik düzeyinde durağandır. Benzer bir şekilde KPSS testinde $\Delta X_{t}$ için boş hipotez kabul edilerek, serinin birim kök içermediği görülmektedir.

Tablo 9: Geleneksel Birim Kök Testlerinin Sonuçları

\begin{tabular}{|c|c|c|c|c|c|c|c|c|}
\hline \multicolumn{9}{|c|}{$X_{t}$} \\
\hline & \multicolumn{3}{|c|}{ ADF } & \multicolumn{3}{|c|}{ PP } & \multicolumn{2}{|c|}{ KPSS } \\
\hline & Sabit & $\begin{array}{c}\text { Sabit ve } \\
\text { Trend }\end{array}$ & Hiçbiri & Sabit & $\begin{array}{c}\text { Sabit ve } \\
\text { Trend }\end{array}$ & Hiçbiri & Sabit & $\begin{array}{c}\text { Sabit ve } \\
\text { Trend }\end{array}$ \\
\hline $\begin{array}{c}\text { Istatistik } \\
\text { Değeri } \\
\end{array}$ & -2.002 & -2.984 & -0.203 & -2.216 & -3.205 & -0.209 & $0.490 * *$ & $0.167 *$ \\
\hline \multirow[t]{4}{*}{$\begin{array}{c}\text { Olasılık } \\
\text { değeri }\end{array}$} & 0.284 & 0.145 & 0.608 & 0.202 & 0.093 & 0.606 & $\begin{array}{c}0.739 \\
(\% 1) \\
0.463 \\
(\% 5) \\
0.347 \\
(\% 10)\end{array}$ & $\begin{array}{c}0.216 \\
(\% 1) \\
0.146 \\
(\% 5) \\
0.119 \\
(\% 10)\end{array}$ \\
\hline & \multicolumn{8}{|c|}{$\Delta \boldsymbol{X}_{t}$} \\
\hline & \multicolumn{3}{|c|}{$\mathrm{ADF}$} & \multicolumn{3}{|c|}{ PP } & \multicolumn{2}{|c|}{ KPSS } \\
\hline & Sabit & $\begin{array}{c}\text { Sabit ve } \\
\text { Trend }\end{array}$ & Hiçbiri & Sabit & $\begin{array}{c}\text { Sabit ve } \\
\text { Trend }\end{array}$ & Hiçbiri & Sabit & $\begin{array}{l}\text { Sabit ve } \\
\text { Trend }\end{array}$ \\
\hline $\begin{array}{c}\text { Istatistik } \\
\text { Değeri }\end{array}$ & $-8.393 * * *$ & $-8.231 * * *$ & $-8.453 * * *$ & $-8.330 * * *$ & $-8.178 * * *$ & $-8.383 * * *$ & 0.115 & 0.067 \\
\hline $\begin{array}{c}\text { Olasılık } \\
\text { değeri }\end{array}$ & 0.000 & 0.000 & 0.000 & 0.000 & 0.000 & 0.000 & $\begin{array}{c}0.739 \\
(\% 1) \\
0.463 \\
(\% 5) \\
0.347 \\
(\% 10)\end{array}$ & $\begin{array}{l}0.216 \\
(\% 1) \\
0.146 \\
(\% 5) \\
0.119 \\
(\% 10)\end{array}$ \\
\hline
\end{tabular}

Not: $* * *, * * *$ sirasıyla $\% 1, \% 5$ ve $\% 10$ anlamlılık değerlerinde, istatiksel olarak anlamlılı̆̆ yansıtmaktadır. $\Delta \mathrm{X}_{\mathrm{t}}$ birinci farkı alınmış seriyi ifade etmektedir. ADF testinde gecikme sayısının belirlenmesi için Schwarz Bilgi Kriterlerinden (Schwarz information criteria, SIC) yararlanılmıştır. PP ve KPSS testinde Barlett çekirdeği (Bartlett kernel) yöntemi izgisel tahmin yöntemi olarak kullanılmış olup, bant genişliği (bandwidth) ise Newey-West yöntemi üzerinden hesaplanmıştır.

Serinin yapısal kırılmalar altında durağanlığının tespiti için Lumsdaine ve Papell (1997) ile Lee ve Strazicich (2003) birim kök testleri gerçekleştirilmiştir. Kırılmalı birim kök testlerinin sonuçları sırasıyla Tablo 10 ve Tablo 11'de yer almaktadır. Lumsdaine ve Papell (1997) test sonuçlarına göre sabitte, trendde ve sabit ile trendde kırılmaya izin veren modellerde $X_{t}$ serisi birim kök içermektedir. Düzey değerinde durağan olmayan $X_{t}$ serisi, birinci farkında ise durağan hale gelmektedir. Kırılma tarihleri incelendiğinde, ilk kırılma olan 1979:01'in ithal ikameci sanayileşme stratejisinden ihracata dayalı büyüme modeline geçildiği döneme, ikinci kırılma olan 2003:01'in ise GEGP'in uygulanmaya başlandıktan sonraki döneme denk geldiği görülmektedir (Tablo 10). 
Tablo 10: Lumsdaine-Papell (1997) Birim Kök Testinin Sonuçları

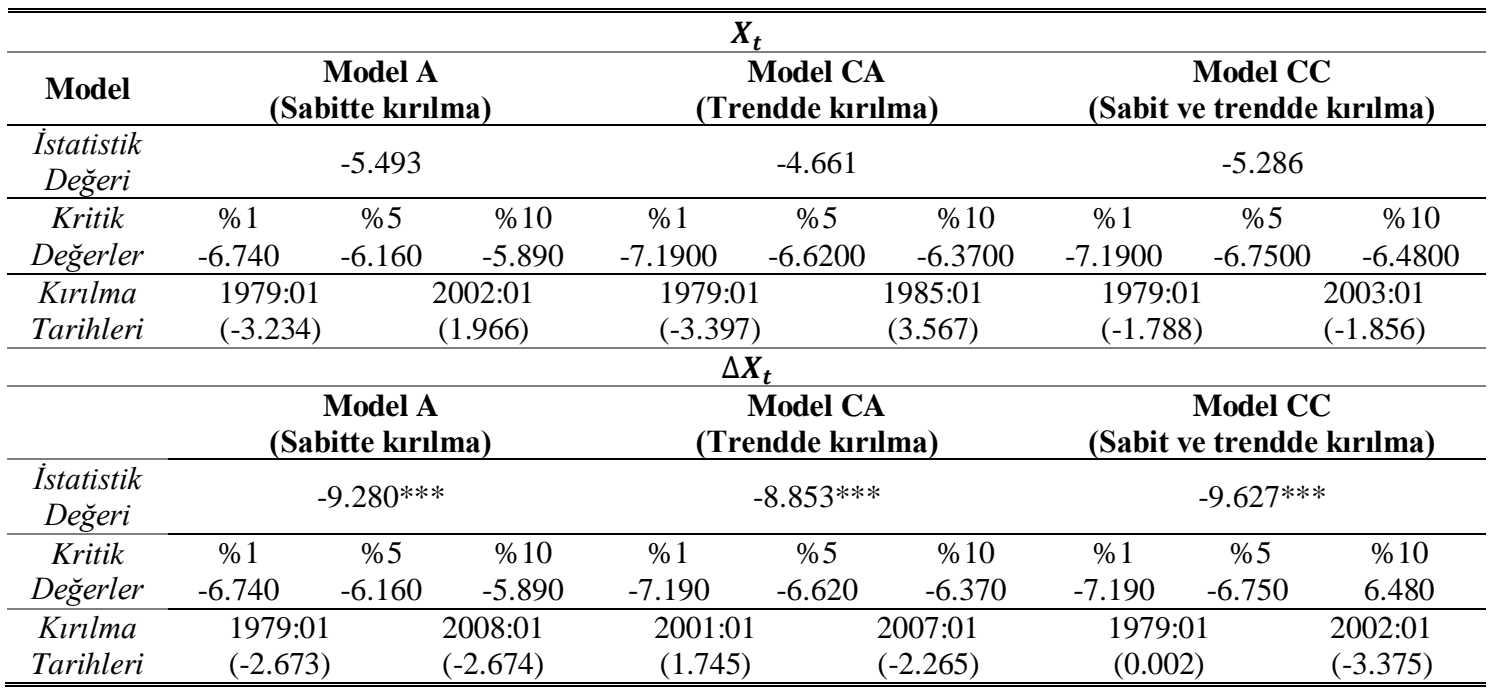

Not: *, **, *** sırasıyla $\% 1, \% 5$ ve $\% 10$ anlamlılık değerlerindeki durağanlığı yansıtmaktadır. $\Delta X_{t}$ birinci fark alınmış seriyi ifade etmektedir. Parantez içindeki değerler sabitte (Model A), trendde (Model CA) ile sabit ve trendde (Model CC) kırılmalara ilişkin t-istatistik değerleridir.

Bir diğer yapısal kırılmalı birim kök testi olan Lee ve Strazicich (2003) birim kök test sonuçları da Lumsdaine ve Papell'e (1997) ile benzerlik göstermektedir. Buna göre, $X_{t}$ serisi için elde edilen LM değerinin, sabit ve trend içeren modellerde kritik değerden düşük olmas1 nedeniyle boş hipotez reddedilememektedir. Diğer bir ifadeyle, $X_{t}$ serisi düzey değerinde birim kök içermektedir. Bununla birlikte serinin birinci farkı alındığında ise sabit ve trend içeren modellerde \%1 anlamlılık seviyesinde durağan hale gelmektedir. Kırılmalardan ilki olan 1993:01'in Türkiye ekonomisini 5 Nisan kararlarına götüren süreci, ikincisi olan 2002:01'in ise GEGP'yi işaret etmesi, kırılmaların ekonomik istikrar programları ile örtüştüğünü göstermektedir (Tablo 11).

Tablo 11: Lee-Strazicich (2003) Birim Kök Testinin Sonuçları

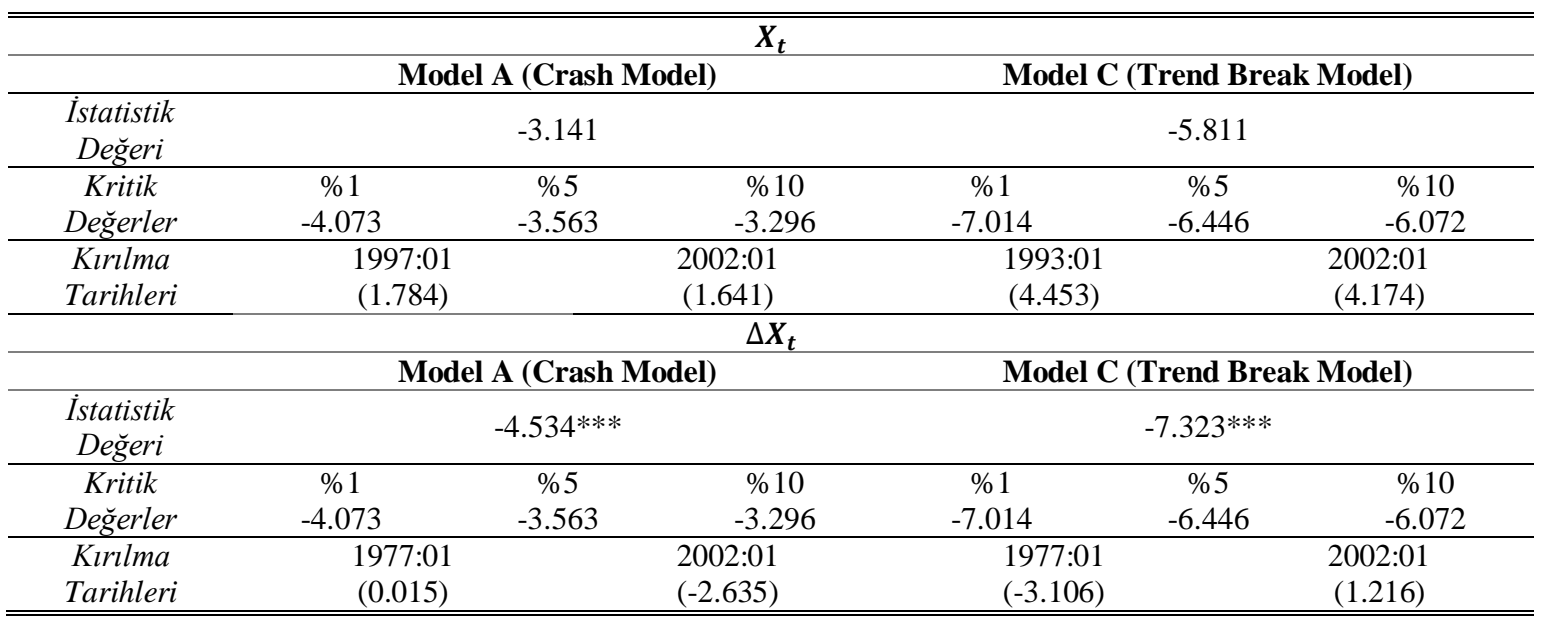

Not: *, **, *** sırasıyla $\% 1, \% 5$ ve $\% 10$ anlamlılık değerlerindeki durağanlığı yansıtmaktadır. $\Delta X_{t}$ birinci fark1 alınmış seriyi ifade etmektedir. Parantez içindeki değerler sabitte (Model A), sabit ve trendde (Model C) kırılmalara ilişkin t-istatistik değerleridir. 
Çalışmada, geleneksel ve yapısal kırılmalı birim kök testleri ile durağanlık analizine tabi tutulan $X_{t}$ serisinin düzey değerinde birim kök içermesi ve durağan olmaması, birinci farkında ise durağan olması nedeniyle Türkiye ekonomisinin orta gelir tuzağında yer almadığını ifade etmek mümkündür.

\section{SONUÇ}

Türkiye ekonomisi, GEGP çerçevesinde 2000'li yılların başında gerçekleştirilen yapısal reformlar ve olumlu küresel konjonktürün etkisi ile birlikte büyüme performansında yakaladığ 1 güçlü ivme sayesinde 2005 y1lında orta gelir grubuna yükselmiştir. Bu tarihten itibaren bir üst gelir grubuna yükselmeyi sağlayacak yapısal dönüşüm adımlarının atılamaması ve küresel likidite koşullarına olan duyarlılı̆̆ın artması, büyüme hızında önemli dalgalanmaların yaşanmasına ve ortalama büyüme hızının yavaşlamasına neden olmuştur. Orta gelir grubunun bir basamaktan ziyade tuzak olacağına ilişkin kaygıların artması neticesinde son yıllarda Türkiye'nin orta gelir tuzağında yer alıp almadığına ilişkin çalışmaların sayısında ciddi bir artış gerçekleşmiştir.

Orta gelir tuzağını ekonometrik yöntemlerle analiz eden literatürdeki çalışmaların neredeyse tamamında Türkiye'nin tuzağa yakalanmadığı sonucuna ulaşılmıştır. Bazı çalışmalarda ise tuzağa yakalanılmaması yüksek gelir grubuna doğru yakınsama ile ilişkilendirilmiştir. Söz konusu durumu, analizlerde ele alınan dönem sonunun, -küresel finansal kriz sonrası dönemde oluşan likidite bolluğuna bağlı olarak- yükselen büyüme oranlarına denk gelmesi olarak değerlendirmek mümkündür.

Analiz döneminin günümüze doğru genişletildiği çalışmamızda, elde edilen ampirik bulgulara göre, literatürdeki diğer çalışmalara benzer şekilde Türkiye'nin orta gelir tuzağında yer almadığ 1 tespit edilmiştir. Bununla birlikte, Türkiye'nin orta gelir tuzağında yer almamasını tutarlı ve doğru bir şekilde açıklayabilmek için ampirik analizi destekleyecek ilave istatistiksel analizler gerçekleştirilmiştir. Bu doğrultuda ülke geneli ve bölgeler/iller için orta gelir tuzağ riski -başta CUI değerleri olmak üzere- istatistiki sınıflandırmalar yardımıyla incelenmiştir. Analiz sonuçlarına göre, orta gelir tuzağı riski taşımayan bölge sayısında son yıllarda gerçekleşen azalmaya karşın orta gelir grubunda yer alan bölge sayısı 2005 yılındaki seviyesine gerilemiştir. Benzer şekilde 2000'li yılların ikinci yarısında orta gelir grubuna yükselen çok sayıdaki il 2014 yılından itibaren düşük gelir grubunda yer almıştır. Bu bağlamda risk teşkil eden bölge ve il sayısındaki azalmanın gelir düzeyindeki artıştan ziyade azalıştan kaynaklandığını ifade etmek mümkündür.

Ülke geneli için yapılan ampirik analizde orta gelir tuzağında bulunulmadığının tespit edilmesi ile bölgeler için hesaplanan istatistiki değerlerde gözlemlenen düşüş, tuzağa yakalanılmamasını yüksek gelir grubuna yakınsama ile açıklamanın güçleştiğine işaret etmektedir. Yüksek gelir grubuna doğru yakınsamanın yerini ıraksamaya bırakması durumunu ise 2013 yılının ikinci yarısından itibaren küresel likidite koşullarının sıkılaşmaya başlaması ve bir dizi iç ve dış şoka maruz kalınmasına bağlı olarak büyüme hızında gerçekleşen yavaşlama ile açıklamak mümkündür.

CUI değerlerinin küresel konjonktürdeki gelişmelerle aynı yönde değişim göstermesi yabancı sermaye yatırımlarına olan duyarlılığı yansıtmaktadır. Büyümedeki yavaşlamanın temel gerekçelerinden biri olan bu durum, sanayi sektöründeki üretim süreçlerinde ithal girdiye olan bağımlılığın devam ettiğine işaret etmektedir. Bu bağlamda büyümenin lokomotifi olan sanayi sektörünün, yüksek gelir grubuna doğru sıçramayı yapacak yapısal dönüşümü henüz tamamlayamadığını ifade etmek mümkündür. 
Orta gelir tuzağının bölgeler ve iller özelinde analizi, Türkiye'de bölgeler açısından ciddi gelir dağılımı eşitsizliklerinin olduğunu ortaya koymuştur. Sanayi sektörü hasılası daha fazla olan batı bölgelerindeki/illerindeki CUI değerleri son yıllarda düşüş gösterse de birçok bölge ve il orta gelir grubunda kalmış veya fazla uzaklaşmamıştır. Diğer taraftan, kırsal nüfusun ağırlığının fazla olduğu ve ekonomisi tarıma dayanan doğu bölgeleri/illeri, kişi başına gelirin yükselme trendine girdiği dönemlerde dahi orta gelir grubundan çok uzakta kalmıştır.

Türkiye'nin yeniden yüksek gelir grubuna doğru yakınsayan ve tuzağa yakalanmadan üst gelir grubuna yükselen bir ülke olabilmesi için küresel konjonktürdeki gelişmelere duyarlılığı azaltan tedbirlerin ivedilikle alınması gerekmektedir. Bu doğrultuda, işgücünün niteliğini ve toplam faktör verimliliğini yükseltecek, tasarruf oranlarını arttıracak, altyapıyı ve kurumsal çerçeveyi güçlendirecek, inovasyonu ve girişimciliği destekleyecek yapısal reformlara ihtiyaç olduğu açıktır.

Gelir dağılımındaki eşitsizliğe yönelik olarak bölgesel kalkınma politikalarının, bölgelerin gelir düzeylerine göre farklılaştırılarak uygun bir şekilde yapılandırılması gerekmektedir. Düşük gelir grubunda yer alan ve tarımın payının yüksek olduğu bölgelerde, Ohno'nun (2009) Ekonomik Gelişmenin Evreleri yaklaşımında ifade edildiği gibisanayileşmeye yönelik adımlardan ziyade öncelikle tarım sektöründeki ölçek ekonomisinin getireceği verimlilik artışları hedeflenmelidir. Diğer taraftan orta gelir grubuna yakın olan veya bu grupta yer alan, sanayi sektörünün payının ağırlıkta olduğu bölgelerde ithal girdilerin yurt içinde üretimini teşvik edici arz yanlı politikalara ağırlık verilmelidir. Bununla birlikte, bölgesel kalkınma ajansları gibi kurumsal yapıların bölgelerin gereksinmelerine karşılık verebilecek yapıda şekillendirilmeleri gerekmektedir.

\section{KAYNAKÇA}

Agenor, P. R. ve Canuto, O. (2012). Middle-income growth traps, The World Bank Policy Research Working Paper, 6210.

Aiyar, S., Duval, R., Puy, D., Wu, Y. ve Zhang, L. (2013). Growth slowdowns and the middle income trap, IMF Working Paper, 71.

Akbulut, G. ve Yıldız, B. (2017). Orta gelir tuzağından çıkışta teşvik politikalarının etkililiği: Türkiye örneği, The Journal of International Scientific Researches, 2(4), 54-71.

Alkan, H. I. ve Ümit, A. Ö. (2018). Orta gelir tuzağının Türkiye açısından incelenmesi ve tuzaktan çıkış stratejileri, Manas Sosyal Araştırmalar Dergisi, 7(4), 97-112.

Ay, A., Akar, G. ve Akar, T. (2016). Middle income trap: a comparision between BRICS countries and Turkey, Economic and Environmental Studies, 16(2), 279-301.

Bal, H., Algan, N., Manga, M. ve Ballı, E. (2016). Orta gelir tuzağının belirleyenleri üzerine bir deneme: Tayland, Türkiye ve Çin örneği, Çukurova Üniversitesi Sosyal Bilimler Enstitüsü Dergisi, 25(3), 347-360.

Banerjee, A., Lumsdaine, R. L. ve Stock, J. H. (1992). Recursive and sequential tests of the unit-root and trend-break hypotheses: theory and international evidence, Journal of Business and Economic Statistics, 10(3), 271-288.

Barro, R. J. ve Sala-i-Martin, X. (1997). Technological diffusion, convergence, and growth, Journal of Economic Growth, 2(1), 1-26.

Bulman, D., Eden, M. ve Nguyen, H. (2014). Transitioning from low-income growth to high-income growth: is there a middle-income trap?, World Bank Policy Research Working Paper, 7104.

Cai, F. (2012). Is there a "middle-income trap"? Theories, experiences and relevance to China, China \& World Economy, 20(1), 49-61.

Daude, C. ve Fernandez-Arias, E. (2010). On the role of productivity and factor accumulation in economic development in latin america and the caribbean, IDB Working Paper, 155.

Dickey, D.A. ve Fuller W.A. (1981). Likelihood ratio statistiscs for autoregressive time series with a unit root, Econometrica, 49(4), 105-1072. 
Egawa, A. (2013). Will income inequality cause a middle-income trap in Asia?, In Bruegel Working Paper, 06.

Eichengreen, B., Park, D. ve Shin, K. (2011). When fast-growing economies slow down: international evidence and implications for China, NBER Working Papers, 16919.

Eichengreen, B., Park, D. ve Shin, K. (2013). Growth slowdowns redux: new evidence on the middle-income trap, NBER Working Paper, 18673.

Felipe, J. Abdon, A. ve Kumar, U. (2012). Tracking the middle-income trap: what is it, who is in it, and why?, Levy Economics Institute of Bard College, 715.

Garrett, G. (2004). Globalization's missing middle. Foreign Affairs, 83(6), 84-96.

Gill, I. ve Kharas, H. (2007). An East Asian renaissance: ideas for economic growth, World Bank Publications, Washington: The World Bank.

Glawe, L. ve Wagner, H. (2016). The middle-income trap: definitions, theories and countries concerned - a literature survey, Comparative Economic Studies, 58, 507-538.

Hawksworth, J. ve Chan, D. (2015). The world in 2050, [Çevrim-içi: https://www.pwc.com/gx/en/issues/theeconomy/assets/world-in-2050-february-2015.pdf], Erişim tarihi: 02.03.2019

Im, F. ve Rosenblatt, D. (2013). Middle-income traps: a conceptual and empirical survey, World Bank Policy Research Working Paper, 6594.

Kesgingöz, H. ve Dilek, S. (2016). Milddle income trap and Turkey, The Empirical Economics Letters, 15(7), 657666.

Koçak, E. ve Bulut, Ü. (2014). Orta gelir tuzağı: teorik çerçeve, ampirik yaklaşımlar ve Türkiye üzerine ekonometrik bir uygulama, Maliye Dergisi, 167, 1-21.

Konya, S., Karaçor, Z. ve Yardımcı, P. (2017). The middle income trap: an assessment in terms of Turkish Economy, Dubrovnik International Economic Meeting, 3(1), 270-287.

Kwiatkowski, D., Phillips, P.C.B., Schmidt, P. ve Shin, Y. (1992). Testing the null hypothesis of stationarity against the alternative of a unit root: how sure are we that economic time series have a unit root?, Journal of Econometrics, $54,159-178$

Lee, J. ve Strazicich, M.C. (2003). Minimum Lagrange multiplier unit root test with two structural breaks, The Review of Economics and Statistics, 85(4), 1082-1089.

Lumsdaine, R.L. ve Papell, D.H. (1997). Multiple trend breaks and the unit root hypothesis, The Review of Economics and Statistics, 79(2), 212-218.

Manga, M., Ballı, E. ve Güreş̧̧i, G. (2019). Orta gelir tuzağı: Türkiye üzerine ampirik bir analiz, Dumlupınar Unniversitesi Sosyal Bilimler Dergisi, 59, 48-60.

Mert, M. (2014). Türkiye'de ve dünyada orta gelir tuzağının talep yönlü boyutuna ilişkin bir tartışma, Maliye Dergisi, $167,93-115$

Ohno, K. (2009). Avoiding the middle income trap: renovating industrial policy formulation in Vietnam, ASEAN Economic Bulletin, 26(1), 25-43.

Ozturk, A. (2016). Examining the economic growth and the middle-income trap from the perspective of the middle class, International Business Review, 25, 726-738.

Öz, S. (2012). Orta gelir tuzağı, EAF Politika Notu, 12-06.

Perron, P. (1989). The great crash, the oil price shock, and the unit root hypothesis, Econometrica, 57(6), 1361-1401.

Phillips, P. C. B. ve Perron, P. (1988). Testing for a unit root in time series Regression, Biometrika, 75(2), 335-346.

Pruchnik, K. ve Zowczak, J. (2017). Middle-income trap: review of the conceptual framework, ADBI Working Paper Series, 760.

Robertson, P. E. ve Ye, L. (2013). On the existence of a middle income trap, University of Western Australia Economics Discussion Paper, 13(12).

Sarıbaş, H. ve Ursavaş, U. (2017). Orta gelir tuzağı: ampirik bir çalışma, AİBU Sosyal Bilimler Enstitüsü Dergisi, 17(2), 37-51.

Tiftikçigil, B. Y., Güriş, B. ve Yaşgül, Y. S. (2018). Does middle income trap exist?: evidence from emerging economies: E7 countries for 1969-2015, Revista Galega de Economia, 27(1), 145-162. 
Tıraşoğlu, M. ve Karasaç, F. (2018). Orta gelir tuzağı: yapısal kırılmalar altında E7 ülkeleri için ampirik bir inceleme, Akademik Incelemeler Dergisi, 13(2), 337-361.

Ünlü, F. ve Yıldız, R. (2017). Orta gelir tuzağını açıklayan teorik ve ampirik yaklaşımlar, Erciyes Üniversitesi İktisadi ve İdari Bilimler Fakültesi Dergisi, 49(Ocak-Haziran), 87-115.

Ünlü, F. ve Yıldız, R. (2018). Orta gelir tuzağının belirlenmesi: ekonometrik bir analiz, Uluslararası Yönetim İktisat ve İsletme Dergisi, 14(1), 1-20.

Woo, W. T. (2012). China meets the middle-income trap: the large potholes in the road to catching-1p, Journal of Chinese Economic and Business Studies, 10(4), 313-336.

Yeldan, E., Taşçı, K. Voyvoda, E. ve Özsan, M. E. (2012). Orta gelir tuzağından çıkış: hangi Türkiye, Cilt 1, İstanbul: Sis Matbaacilik.

Yılancı, V. (2009). Yapısal kırılmalar altında Türkiye için işsizlik histerisinin sınanması, Doğuş Üniversitesi Dergisi, $10(2), 324-335$.

Y1lmaz, G. (2014). Turkish middle income trap and less skilled human capital, CBRT Working Paper, 14/30.

Zivot, E. ve Andrews, D. (1992). Further evidence on the great crash, the oil-price shock, and the unit root hypothesis, Journal of Business \& Economic Statistics, 10(3): 251-270. 


\section{Extended Summary}

\section{Determination of the Middle Income Trap for Turkey and Its Sub-Regions}

Concerns about the growth performances of middle income countries have been frequently expressed by both academicians and policymakers in recent years. Accordingly, the trap risk of countries that continue the policies implemented in the transition from low income group to middle income group is getting increased. For countries that remain in the middle income group for a long time as a result of decelerating growth rates and whose probability of transition to high income group decreases in the near future, this situation is defined as middle income trap in the literature.

The middle income trap poses a serious risk factor in terms of sustainable economic growth for economies which could not yet completed structural transformation like Turkey. After the November 2000 and February 2001 crises, Turkish economy has carried out structural reforms in many areas with transition to the strong economy program. Achieved a significant growth performance and reached the middle income group with the effect of the global liquidity abundance during the "Great Moderation" period. However, per capita income, which has long been well below the high income group has led to discussions about whether this income group will be a trap or just a step. In this context, for Turkey which seems unlikely to reach group of high income countries in near future, the necessity of examining the risk of middle income trap has emerged.

In the literature, when the examining the studies which concerning of the Turkey, it is seen that the studies has focused the determination of the trap for the whole country. The studies that examine the existence of the trap in terms of sub-regions considering the differences between regional income levels are extremely limited. In addition to this, it is seen that some studies that analyse the existence of middle income trap for different periods for the whole country and found that there is no middle income trap have explained this situation with convergence to high income group. It should be also note that this situation can be considered as the end of the period of analysis that corresponds to the rising growth rates due to the abundance of liquidity in the post-global financial crisis period.

The aim of this study is to examine whether there is the middle income trap for Turkey's level of general and sub-regions. In this direction, the existence of the middle income trap is analysed for the country level through traditional and structural break unit root tests based on Robertson and Ye's (2013) approach, on the other hand the statistical classifications -mainly Catch-Up Index (CUI)- are employed for the sub-regions.

The data used in econometric analysis is annual and covers the period of 1960-2018, while the data used in statistical classification-based analysis is also annual and covers the period of 2004-2017. GDP per capita series that used for sub-regions, retrieved from the Turkish Statistical Institute database, while GDP per capita series that used for Turkey and USA, taken from the World Bank database.

In our study that analysis period is extended is in a similar way to other studies in the literature, it was determined that Turkey is not being in the middle income trap. However, when the GDP per capita level is analysed with the help of statistical classifications -especially CUI values- it is seen that is not possible to explain not fall into the trap with convergence to the high income group. Since the second half of 2013, the tightening of global liquidity conditions and exposing a series of internal and external shocks caused a slowdown in the growth rate. This has caused the divergence situation to replacement the convergence situation. 
In this study, middle income trap was also analysed for regions and provinces. According to the results of the analysis, despite the decrease in the number of regions without middle income trap risk also the number of regions in the middle income group has been declined to the level of 2005. Similarly, a large number of provinces that have reached to the middle income group in the second half of the 2000s, have been in the low income group since 2014. In this context, it is possible to state that the decrease in the number of regions and provinces posing a risk is due to a decrease rather than an increase in the income level.

In order to re-convergence the high-income group and to reach the upper income group without getting trapped, Turkey must take the measures that reduce the sensitivity to developments in the global economic conjuncture. Accordingly, it is clear that there is a need for structural reforms that will increase the quality of labour force and total factor productivity, increase saving rates, strengthen infrastructure and institutional framework, and support innovation and entrepreneurship. However, regional development policies need to be structured appropriately by differentiating according to income levels of the regions in order to reduce the inequality in income distribution. 